\title{
Not Written in the Stars \\ Vitek Tracz, founder of open access publisher BioMed Central, talks to Richard Poynder*
}

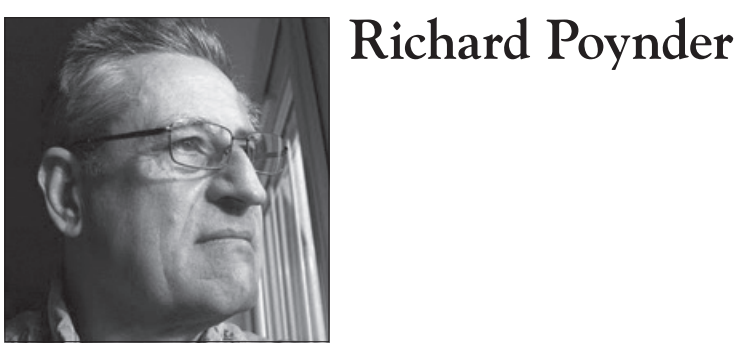

Richard Poynder writes about information technology, telecommunications, and intellectual property. In particular, he specialises in online services, electronic information systems, the Internet, Open Access, e-Science and e-Research, cyberinfrastructure, digital rights management, Creative Commons, Open Source Software, Free Software, copyright, patents, and patent information.

He has contributed to a wide range of specialist, national and international publications, and edited and co-authored two books: Hidden Value and Caught in a Web, Intellectual Property in Cyberspace. He has also contributed to radio programmes.

E-mail: richard.poynder@gmail.com

Website: http://www.richardpoynder.co.uk
Chairman of the Science Navigation Group, ${ }^{1}$ Vitek Tracz was born in a Jewish shtetl in Poland during the Second World War. When the Germans invaded Poland his parents fled to Russia, and spent five years in Siberia. Those members of his family who stayed in Poland were killed by the Germans.

After the war Tracz and his family returned to Poland, before subsequently emigrating to Israel. Keen to attend film school Tracz later moved to London, where he settled. After making a number of films, however, he turned his hand to medical publishing, and went on to build a series of successful publishing businesses, including Gower Medical Publishing, Current Drugs and the Current Opinion series of journals.

\section{Modus operandi}

Tracz quickly developed a distinctive modus operandi, creating mould-breaking businesses that he then sold on to large publishing companies like Harper \& Row, Elsevier, and Thomson Corporation, invariably at very attractive prices.

Constantly on the look-out for challenging business ventures, by the late 1990s Tracz had become convinced that the disruptive nature of the Internet would make it increasingly difficult for scientific, technical and medical (STM) publishers to charge readers to access scholarly journals, particularly as the focus of their businesses began to shift from selling print journals, to licensing large electronic databases like Elsevier's ScienceDirect. ${ }^{2}$

For a start, researchers were discovering that they were now easily able to distribute their research for themselves over the Web. Since 1991, for instance, physicists had been self-archiving their papers in the $\operatorname{arXiv}^{3}$ repository; and there were growing calls for academics in other disciplines to follow suit. ${ }^{4}$

At the same time, the "serials crisis" had sparked a tide of unrest amongst librarians, who were struggling to pay for all the journals and other scholarly information their faculty demanded; unrest that 
was beginning to coalesce around the incipient Open Access Movement. ${ }^{6}$

Advocates of Open Access (OA) argue that in a networked world publicly-funded research should be made freely available, not sold as part of a paidfor online service. Their reasoning is that researchers give their papers to publishers, and do all the essential peer review work, without any payment. Once the print and distribution costs have been removed from the system, therefore, most of the costs of publishing have gone away.

Intrigued by the challenge this posed for STM publishers, in 1998 Tracz created the first open access publisher, BioMed Central (BMC).

What was radical about BMC was not so much that it was an online-only publisher, but that it had turned the traditional publishing model on its head: instead of charging readers to read scholarly papers, BMC charged authors (or more usually authors' funders or institutions) to publish them - by means of an article processing charge (APC) of $\$ 525$.

By front-loading the costs in this way, $\mathrm{BMC}$ was able to meet growing demands that publicly-funded research be available outside financial firewalls, while still covering the cost of organising peer review, and marking up and editing the papers.

\section{Credibility}

Having acquired a reputation amongst cognoscenti of the STM publishing community as a creative entrepreneur with an uncanny knack for turning unlikely ideas into successful businesses (invariably by exploiting innovative technology), in launching BMC Tracz provided the OA Movement with a credibility not unlike that provided to the Open Source Movement when, in the same year as BMC was founded, IBM announced that it would support Apache, the Open Source web server software. ${ }^{8}$

Importantly, Tracz had developed a plausible business model - one that was later also to encourage a number of traditional publishers to experiment with Open Access themselves.

In addition, by appointing the articulate and widely respected publisher Jan Velterop to manage $\mathrm{BMC}$, Tracz was able to position the company as a spokes-organisation for the OA Movement, and thus an ally of those who believed that scientific research should be freely available.
With the assistance of Velterop, Tracz also became an effective behind-the-scenes advocate, encouraging, for instance, the then director of the US National Institutes of Health, ${ }^{10}$ Harold Varmus, to create the free literature repository PubMed Central, ${ }^{11}$ and recruiting researchers, librarians and key decision-makers to the OA cause.

\section{While Tracz believed that in time publishers would have no choice but to accept OA, it became clear that they were not prepared to give up the benefits of the subscription-based model without a fight.}

It was quickly apparent however that, whatever its merits, OA publishing would never be the pot of gold that STM publishers were accustomed to. By insisting that authors assign copyright as a condition of publishing their papers, scholarly publishers had, since the war, managed to acquire exclusive ownership of a great deal of the world's research output - thereby enabling them to earn profits that most industries would give their eye teeth for.

Moreover, as publishers moved to electronic delivery it seemed that profit levels could be even greater, since publishers were increasingly no longer selling print journals that libraries could own in perpetuity, but temporary access to single papers in vast electronic databases containing millions of individual scholarly papers. Since libraries would never actually "own" copies of these papers, publishers could, in theory, charge users every time a paper was accessed. ${ }^{12}$

Unsurprisingly therefore, rather than embracing $\mathrm{OA}$, publishers were more inclined to conduct aggressive lobbying campaigns aimed at neutralising OA initiatives. As a result of publisher lobbying, for instance, PubMed Central was effectively emas- 
culated before it even saw the light of day. ${ }^{13}$

While Tracz believed that in time publishers would have no choice but to accept OA, it became clear that they were not prepared to give up the benefits of the subscription-based model without a fight. In short, it was going to require more than an interesting new business model to recruit them to the cause.

\section{What is indisputable is that the STM publishing industry has (to date) proved itself capable of hamstringing every single OA initiative proposed.}

\section{Publicity coup}

Concluding that the OA movement would therefore need to persuade funders and politicians to force OA on the world, in 2003 Tracz (with Velterop) set out to convince the then Chair of the UK House of Commons Science and Technology Committee, ${ }^{14}$ Ian Gibson, ${ }^{15}$ to conduct an enquiry ${ }^{16}$ into scientific publishing. After some serious wining and dining of Gibson this they succeeded in doing.

The resulting enquiry provided a publicity coup for the OA movement, and attracted the attention of politicians and research funders around the world. It also sparked a steady stream of further reports, declarations and, in some cases, firm commitments to $\mathrm{OA}$.

In October 2005, for instance, the Wellcome Trust introduced a mandate requiring that all papers resulting from research that it funded were to be made open access. ${ }^{17}$ And in April 2006 the European Commission published a report urging $\mathrm{Eu}$ ropean science funders to guarantee open access to research outputs. ${ }^{18}$ The Select Committee enquiry also undoubtedly influenced the growing number of US proposals.

When, in July 2004, the Select Committee report ${ }^{19}$ was published, however, it was a mixed bless- ing for Tracz. For while it endorsed the principle of $\mathrm{OA}$, it placed a greater stress on mandating researchers to self-archive papers they published in traditional subscription-based journals, than it did on trying to insist that they publish in new-style OA journals.

Comments one publisher, speaking on condition of anonymity, "The Select Committee didn't give OA the mandate that Tracz was expecting, because late on in its enquiry it found out about the practice of self-archiving, and realised that an awful lot of Open Access can be achieved in that way." ${ }^{20}$

\section{Growing frustration}

Evidently the Select Committee concluded that, rather than make the politically-charged recommendation that authors be instructed to choose one business model over another when publishing their papers, it was enough simply to mandate them to self-archive their papers regardless of the type of journal in which they had been published. No doubt to Tracz's growing frustration, subsequent OA initiatives have tended to follow suit, placing a greater emphasis on self-archiving than on $\mathrm{OA}$ publishing. This, for instance, was the thrust of the voluntary NIH Policy on public access to research introduced in May 2005, ${ }^{21}$ as it was of the American Center for CURES Act of 2005.22

It is also the logical consequence of the recently proposed Federal Research Public Access Act of 2006 (FRPAA). The most radical US bill in support of OA to date, if enacted the FRPAA would introduce a mandate requiring publicly funded papers to be made freely available on the Web within six months of publication. ${ }^{23}$

Moreover, unlike earlier US proposals, the FRPAA would not insist that papers are archived in a central repository like PubMed Central. Since this is likely to encourage federal agencies to mandate deposit in institutional repositories, it would increase the emphasis on self-archiving. ${ }^{24}$

In short, while the many OA proposals are all potentially beneficial to BMC, they have increasingly tended to prioritise self-archiving over $\mathrm{OA}$ publishing.

In retrospect, this is not surprising. What has become increasingly clear is that researchers, their institutions, and research funders have more to 
gain - at least in the short term - from researchers continuing to publish in high-impact established subscription-based journals and then self-archiving their papers, than they do from researchers restricting themselves to publishing in low-impact OA journals, even though in the latter case responsibility for making the research available on the Web is taken on by the publisher. ${ }^{25}$

More importantly, perhaps, there has been a growing feeling that wresting proprietary control from the grasp of large monopolistic publishers should take precedence over supporting new journals that, many frequently worry, rely on an "untested business model."

\section{Important questions}

For Tracz this has raised two important questions. First, can a small private company hope to compete against a large multinational industry now worth around $\$ 8.5$ billion when its very raison $d^{\prime}$ 'etre ${ }^{26}$ is viewed by that industry as a serious threat to the status quo - particularly when that industry is canny enough to make concessions when necessary, ${ }^{27}$ and powerful enough to mount huge lobbying campaigns to defang $\mathrm{OA}$ initiatives? ${ }^{28}$

What is indisputable is that the STM publishing industry has (to date) proved itself capable of hamstringing every single $\mathrm{OA}$ initiative proposed.

Second, can the publishing model pioneered by Tracz truly provide long-term sustainability? More specifically, can BMC attract and retain a sufficient number of customers to keep the company afloat - bearing in mind that in the world of $\mathrm{OA}$ publishing the customers are no longer academic librarians charged with buying traditional journal subscriptions, but the researchers who generate the content in those scholarly journals, and who do the peer review essential for maintaining quality control..$^{29}$

When he gave evidence to the Select Committee Enquiry in 2004, Tracz predicted that BMC would achieve profitability in 2006. This, he told British politicians, was based on the assumption that the company would need article submission levels to reach 2,000 a month before it became selfsupporting. At that point in time, he added, BMC was receiving 500 to 600 papers a month.

How does the situation look today? Unfortu- nately, while the number of journals has grown to 158 , submissions have reached only 1,200 papers a month. 30

In short, it appears that Tracz overestimated potential growth rates. Moreover, says an industry insider familiar with the BMC business, he also underestimated how much it would cost to produce peer-reviewed journals, even after print and distribution costs have been removed from the equation.

"Managing a peer review process demands a lot of man-hours," he explains, adding that since the number of papers submitted to BMC has grown more slowly than expected the company has also been unable to exploit anticipated economies of scale.

\section{Rebelled}

In short, Tracz made the strategic mistake of entering a new market with a significantly under-priced product. In an attempt to rectify the situation, therefore, in July 2005 BMC more than doubled its APC rate, from $\$ 525$ to $\$ 1,400$ ( $£ 750$ ). ${ }^{31}$

Clearly this was a risky thing to do, and around 60 BMC editors immediately rebelled, with many refusing to implement the rise. "Currently we charge authors $£ 330$ per article. Under the new contract this would rise to $£ 750$," complains $\mathrm{Ri}$ chard Feinman, co-editor-in-chief of Nutrition and Metabolism, ${ }^{32}$ and one of the editors refusing to sign the new contract.

Events came to a head in May 2006 when, without any consultation, BMC issued a new Code of Conduct for Editors. In discussing the document on a listserv, 43 dissident editors realised that they all shared a number of grievances, and so formed a committee to negotiate with BMC. This in its turn led to a bruising news story in The Scientist. ${ }^{33}$

BMC editors, The Scientist reported, were not only angry about the price rise, but upset that the new contract would mean reducing the number of fee waivers that they would be able to offer contributors from developing countries. ${ }^{34}$ It would also require some editors of BMC's independent journals to sign over ownership of their journal to BMC.

"In the e-mails I have been receiving from other editors a common complaint I am hearing is that they feel they have to some extent been swindled," says Feinman. "We may be naïve, but we agreed to 
run journals with BMC that had certain characteristics, including an acceptable APC."

Other BMC editors, however, have been quick to brand the dissidents as idealists with little understanding of how publishing really works.

"I have always been, and remain, a strong supporter of Open Access, but I have always also stressed that someone must pay the bill, and that for $\mathrm{OA}$ to survive and fulfil its promises, it must adopt a financially viable business model to cover its costs," says Maged Kamel Boulos, editor-in-chief of the International Journal of Health Geographics. ${ }^{35}$ David Lipman, director of the US National Center for Biotechnology Information, and co-editor-inchief of BMC's Biology Direct, ${ }^{36}$ is also critical of the dissidents. Speaking to The Scientist he characterised their actions as "bizarrely emotional."

As the dispute spread to the Liblicense mailing list, ${ }^{37}$ however, it was also revealed that under the new contract editors would be paid a 20\% share of revenues. This, argued critics, would create a conflict of interest issue for editors, and so breach the ethical standards of scholarly publishing.

To add to BMC's difficulties, Velterop had by now left the company, taking a new position as "internal champion" of OA at the STM publisher Springer in August 2005. ${ }^{38}$ Deprived of his authority and considerable negotiating skills the company has struggled to appease the irascible editors.

\section{When the history of $O A$ is written, the current contretemps will doubtless be viewed as little more than (as Velterop's successor at BMC Matt Cockerill expressed it to The Scientist) the inevitable 'growing pains' of $\mathrm{OA}$.}

\section{Growing pains}

When the history of $\mathrm{OA}$ is written, the current contretemps will doubtless be viewed as little more than (as Velterop's successor at BMC Matt Cockerill expressed it to The Scientist) the inevitable "growing pains" of OA. Indeed, Feinman himself is keen to stress that the issues raised by the editors "are points of discussions, not bed-rock disagreement."

Adds Feinman, "I suspect most of the editors would be willing to accept the APC (at least tentatively) if there were no change in the waivers. The waivers are the life blood of the freedom we have as editors, and some journals such as the International Journal for Equity in Health ${ }^{39}$ exist primarily on contributions from developing countries."

Nevertheless, the event has served to draw attention to the inevitable tension between the idealism of many in the OA movement and the financial realities of scholarly publishing.

It has also led to some suspicion about Tracz's motives. "Most scientists are fed up with publishers making increasingly large profits out of the work of (largely) unpaid scientists as authors, reviewers and editors," says Neville Punchard, co-editor-in-chief of the Journal of Inflammation. 40 "I think those scientists involved as editors hoped that BMC would not allow this to happen, but are now beginning to realise that $\mathrm{BMC}$ is just like any other publisher when it comes down to it, and has to make a profit."

What BMC has yet to achieve, he concludes, is a workable formula that can provide a "balance between OA (to keep editors and other scientists happy) and profit (to keep the owners happy)."

In other words, it has underlined the importance of creating an acceptable and sustainable business model for OA.

\section{Secrecy}

What has surely exacerbated the situation is that like many small private companies, $\mathrm{BMC}$ is not very accomplished at PR. And by appearing reluctant to consult and work with the editors it has tended to fan the flames of suspicion.

As Feinman complains, "In being asked to sign the new contracts we are being asked to do something that we don't want to, but it was presented as if we apparently have no choice. BMC is treating it 
as though it were just a formality."

At times the company also appears a little paranoid about sharing information with those outside the company - as I discovered when I tried to update this interview, and when I tried to obtain a comment on the dispute with editors.

Unfortunately, this tends to give the impression that BMC prefers secrecy over transparency - an unfortunate public image for a company founded on the principle of openness. And it has come to seem all the more impenetrable and unresponsive to the outside world since Velterop left.

What this no doubt reflects is the character of the company's founder. For Tracz has always preferred working behind the scenes, and likes to maintain a very low public profile. As the industry insider, puts it "Essentially, I think he is a shy person, or at least a private one. He has a reluctance to personally take his ideas into the public arena. This is a pity because they would really benefit from being presented by him in public."

He adds, "I think more could perhaps be done on the diplomatic front, and BMC should involve the people who will be affected by its decisions, and who otherwise might misunderstand its intentions."

The need for a more user-friendly approach is likely to intensify as the company struggles to reach profitability. "I think BMC will need about $\$ 2,000$ per article before it begins to make a profit," says the industry insider. "So I think it is inevitable that the article processing charges will have to increase [again]."

Cockerill, however, remains keen to project an upbeat picture of the situation. "We anticipate breaking even soon," he insists, "though not necessarily in 2006."

\section{Instinctive emotional objection}

But what happens if the APC does indeed have to rise to $\$ 2,000$, and profitability still remains elusive?

This will, no doubt, depend on how Tracz views the company: is it a cause that he intends to see through to the bitter end, or just another business venture, intended - like his other businesses - to make him a lot of money?

Tim Hailstone, co-founder of Gower Medical (who has known Tracz for many years), believes that his adoption of OA was essentially "an instinctive emotional objection to the power of Elsevier."

The temptation, therefore, is to view his motivation as being on a par with IBM's decision to support the Open Source Movement: where the computer giant saw Open Source as a competitive stick with which to beat archrival Microsoft, Tracz perhaps viewed Open Access as a tool to subvert large STM publishers like Elsevier - although clearly in more of a David and Goliath way!

But is that right? What is it that really motivates Vitek Tracz?

"He is difficult to read sometimes, and so it can be hard to know what he is thinking," comments the industry insider. "Sometimes you think he just likes big ideas and is driven to realise them; at other times you feel he is evangelising not from a conviction, but because he is looking for an opportunity to make money."

Ask Tracz directly, and he denies that money has ever been a significant motivation. "I am perfectly happy not to have money," he says, "although it is nice to have it."

The publisher I spoke to, however, dismisses such claims with a wave of the hand. "Vitek can be very seductive, but under his charm he's pretty ruthless. He can absolutely judge his prey and adapt accordingly. So behind this charming dinner companion expressing interest in your work, and in your thoughts, you sense a calculator working away in the background, trying to establish whether there is any money to be made from talking to you."

Moreover, he adds, Tracz's complex corporate structure, and the elaborate financial arrangements he puts in place in order to maximise his financial gains when selling a company, belie any claim that money is not important to him. "His wealth is ultimately completely offshore; so when he sells a business, some of it will go to paying off a loan, and the rest will disappear overseas, to a bank in Switzerland, or wherever. It seems to be part of some amazing tax planning strategy."

\section{Got religion}

Yet during his rare public appearances it is hard not to believe that Tracz is a man who has got religion. 
When giving evidence to the UK Select Committee Enquiry, for instance, he spoke so quickly, so excitedly, and at such length that the chair Ian Gibson, pleaded: "May I ask you quite humbly to keep the answers a bit shorter, and answer the question? I understand the enthusiasm and determination, but I do not want to be here at midnight and I am sure you do not either, and we should like to get some more information from you." ${ }^{41}$

Tracz is also at pains to stress that $\mathrm{OA}$ is more than just a commercial issue. While conceding that he is a businessman, and so believes that making profits is a legitimate activity for scholarly publishers, he adds, however, that since OA is plainly beneficial to society "there is an ethical reason for insisting that it happens."

Hailstone thinks that while he may have been powerfully motivated by money when he was younger, nowadays Tracz is more interested in leaving his mark on the world. "Vitek has got a lot of money now. I think he would quite like to be famous for something. He loves the idea that he could be the guy who was responsible for completely changing STM journal publishing. And he loves the idea that $\mathrm{BMC}$ is in some ways the spokes-organisation for the OA Movement."

But why does it matter what motivates Tracz? It matters because the danger facing $\mathrm{OA}$ today is that if he pulls the plug on BMC, then sceptics' claims that a viable OA business model is not possible will be seen to have been vindicated.

The threat is real. In the past, says Hailstone, Tracz has been happy to drop businesses if he sees no future for them - a fate, for instance, that befell Praxis Press, a clinical medicine web service for practising physicians that Tracz co-founded in 2002, but subsequently walked away from.

The fear therefore is that if Tracz were to abandon BMC, it could inflict serious damage on the OA movement. "Whether it likes it or not, BMC is carrying a lot of open access on its shoulders," says Feinman, "so it should feel an obligation to do things right."

In reality, of course, the logic of OA is sufficiently compelling that it is no longer a matter of if, but when - irrespective of business models. For while today's sanctification of market forces might appear to imply that "the market" will be the only arbiter of OA's fate, anyone with a historical perspective will know that most societies will always find a way of funding something if its social value is perceived to be high enough. The case for OA has now been argued so often, and so well, that it is surely a done deal.

\section{New territory}

Nevertheless, the failure, or abandonment, of $\mathrm{BMC}$ would certainly slow progress. The challenge for Tracz, therefore, is to keep the show on the road while the larger OA struggle plays out.

The problem, says Hailstone, is that Tracz is not actually very good at the day-to-day task of running a business. "Vitek is better at building businesses to a certain level than he is at running them. So he is very good at spending money on a business, but not actually very good at making money out of it."

The alternative, of course, would be for Tracz to sell BMC. Again, says Hailstone, this may not be possible. "I won't say that Vitek will never be able to unload BMC," he says, "but of all the businesses he has started I think it is the least likely that he will be able to sell."

Certainly eight years after founding the company, Tracz has apparently yet to find someone willing to take it off his hands, despite frequent rumours that a deal is on the cards. Maybe a sale is being negotiated right now. But we don't know.

If not, however, Tracz is surely entering new territory: unable to sell the company, he may have no choice but to soldier on. And without Velterop there is perhaps no one better qualified than Tracz to run the company. On the other hand, he will be increasingly conscious that subsidising BMC indefinitely is not a practical solution, even for a wealthy entrepreneur committed to a worthy cause.

Time will tell what happens. Clearly how history judges Tracz will depend on the way events unfold. "BMC," predicts the industry insider, "is likely to go through a patchy period, both with editors and the market, but these are growing pains, and I think it has a reasonable future. I do hope it succeeds, because it really has introduced a new paradigm."

Either way, he adds, "Vitek should have a star role in the history of Open Access, because he was one of the first to pick up the signals, and to get in touch with Varmus, and the other people who 
started PLoS (initially as a pressure group). He has also been talking to NIH for a long time. More importantly, he had the vision and the guts to do something about OA."

\section{Not typical}

What is undeniable is that Tracz is not a typical entrepreneur, both in temperament and in style. With a reputation for eccentric dressing, for instance, he is a far cry from the well-groomed entrepreneurs that inhabit Silicon Valley.

Hailstone relates how, when he and Tracz turned up at the oak-panelled City of London solicitors to complete the sale of Gower Medical, Tracz arrived in a leather jacket, with his trousers tucked into a pair of boots. Due to his unconventional dress, says Hailstone, when Tracz asked where the toilet was, "the snooty receptionist thought he was a taxi driver and directed him to the public toilet across the street."

But as Tracz explained to a former employee, "Even if I were to spend lavish amounts of money on my appearance and attire I would always end up looking like a refugee."

To his credit, however, Tracz inspires a degree of loyalty and commitment from those who work for him that most Silicon Valley CEOs would die for.

\section{In reality, of course, the logic of $O A$ is sufficiently compelling that it is no longer a matter of if, but when - irrespective of business models.}

Tracz's various businesses are run out of an office block in Cleveland Street - in an area of London that artists and writers like Dylan Thomas and George Orwell, who between the two world wars frequented the Fitzroy Tavern in neighbouring Charlotte Street, dubbed Fitzrovia. ${ }^{42}$

Across the street from Tracz's office is the Courtauld Institute of Biochemistry, one of the many buildings dotted around Fitzrovia that belong to University
College London. ${ }^{43}$

Tracz arrives three minutes late; an insignificant delay that nevertheless elicits solicitous enquiries as to whether I had been waiting long.

Dressed in a plastic macintosh, walking with a slight stoop, and with an air of distraction, Tracz could be mistaken for a down-at-heel civil servant fretting over a lost briefcase. With his mac removed, however, his clothes emit a more luxurious air, particularly the dark shirt with puckered cloth that, to my untutored eye, looks like seersucker.

His large office is sufficiently bare that it is immediately apparent that Tracz conducts his real business elsewhere; perhaps in the triangular house he built for himself with the proceeds from the sale of his first company? The regulation plastic furniture and workmanlike bookshelves contrast oddly with the wooden floorboards and tasteful wooden slats on the windows, the latter currently shutting out what travel guides like to call the "neglected charm" of Fitzrovia; neglected charm that today is suffused with the gloomy atmosphere peculiar to late autumnal London afternoons.

Dominating one corner of the room is a wooden architect's desk - the very one perhaps on which Tracz designed his house? Pinned to it is a poster advertising an exhibition of drawings by the Polish graphic artist Andrzej Krauze. ${ }^{44}$

On the other side of the office is a large desk dominated by an oversized computer screen and a keyboard. Apart from several rows of catalogues from art auctioneers Sotheby's and Christie's, the bookcases house little more than a few maps and a large chrome coffee machine. Tracz's first action on entering the room is to switch on the coffee machine and make a stiff shot of dark espresso.

At first restrained, Tracz becomes increasingly effusive as the interview proceeds. Evidently having concluded that what excites journalists more than anything else are good human-interest stories, practically every answer threatens to balloon into a series of increasingly amusing and fascinating anecdotes and observations. Sadly, it later transpires that many of his stories cannot be published, for reasons of commercial confidentiality. Two hours later, his face flushed, Tracz's stories are still flowing. My tape, alas, runs out, and I have to rush to catch my train. 


\section{Interview with Vitek Tracz}

$R P$ : Can you start by saying something about your background?

VT: I was born in 1940 in a Jewish shtetl ${ }^{45}$ on the border between Poland and Russia. That was when the Russians occupied the area. So you could say I was conceived in Poland and born in Russia without my parents moving; it was the borders that moved. My family then lived in Siberia for several years.

RP: Were you relocated to Siberia because your family was Jewish?

VT: It was more complicated than that. We were looking for some members of the family who had moved there, not because they were Jewish but because it was easy to be sent to Siberia in those days. They were out there working in a mine. It wasn't a prison camp, and there were no guards, but they weren't allowed to leave. In any case, the nearest habitation was 150 miles away. When we arrived my father was immediately made to go and work in the mine too, so we got stuck there for a while - not as a result of a sentence; it was just that life was like that then.

RP: Your family were dissidents?

VT: My family were from Poland, they were bourgeois, and they were merchants; but my parents were actually communists. The Polish communist party was considered Trotskyite ${ }^{46}$ by the Russians however, and had been thrown out of the Comintern ${ }^{47}$ in 1936. All in all, therefore, it was a little problematic to be a Polish communist.

RP: Your family subsequently emigrated to Israel? VT: Later, yes. We returned to Poland in 1945. There my father joined the army, and I grew up in Warsaw, where I studied mathematics. We went to Israel when I was 21.

RP: But you personally didn't stay long in Israel?

VT: No. I continued studying mathematics for a year there, but I wanted to make movies - so I decided to go to Europe to attend a film school. I came to England on my way to France and fell in love with London.

I went to film school at the London Polytechnic $^{48}$ and the Slade School of Art, ${ }^{49}$ and then got a fellowship at the Department of Art History in the University of Essex. All that time I was writing scripts and trying to get into the movie industry. It was a very hard industry to get into.

\section{Gower Medical Publishing}

RP: You made a film about a Queen of Sweden!

VT: Much later I made an allegorical comedy that had a small part about a young Queen of Sweden..$^{50}$ Before that I made a lot of medical films, for which I started, with two friends, my first company - Medi-Cine. Some years later, after making my first and only feature film, I decided to stop making films and to become a publisher, and I started Gower Medical Publishing. The aim was to publish highquality colour medical atlases and slide collections, and to sell them both to drug companies as a marketing giveaway and through bookshops.

RP: Gower was founded with the publisher Tim Hailstone? ? $^{51}$

VT: Tim arrived about a year later: I persuaded him to join me from the medical publisher Churchill Livingstone. ${ }^{52}$ I was worried I didn't know enough so I wanted someone working with me who really knew the business.

Tim is a very special sort of person. The way he responded when I asked him to join me says a lot about the man. "Let me think about it a bit and speak to my wife, and I'll give you an answer tomorrow," he replied. Since it was a big decision to make I was very impressed with this: in England nobody gives you an answer tomorrow.

$R P:$ And you got an answer the next day?

VT: Sure. He came to see me the next morning. Tim has this wonderful habit, by the way, that when he sits at your desk your desk becomes his desk: by the simple device of moving the telephone this way and positioning himself that way and so on.

So he sat down, picked up my phone, and called his boss at Churchill Livingstone. "I'm sitting at Vitek's desk and I just wanted to tell you that I am resigning," he said. "I'm going to join Vitek's new company and I wanted to discuss with you how long you need me."

When he put the phone down I commented that his wife must have really liked the idea of this 
new job.

"Actually it's a little bit embarrassing," he replied, "because I didn't have time to talk to her last night. But you know I have a feeling that she will really like it."

Tim and I went on to have a wonderful time together.

RP: How did you fund your early business ventures? VT: We started Medi-Cine with very little money. We were able to do this by getting early commissions from pharmaceutical companies for educational films for doctors. Later, when we started Gower, we went to visit drug companies, told them we were going to make a fantastic book and showed them a few sample pages. We then sold the books to them a chapter at a time, asking them to pay one third in advance for each chapter. So the whole thing was virtually self-financing. It also became very successful.

RP: You sold Gower to Harper $\mathcal{E}$ Row in 1984 right? VT: Yes. I get bored quickly, and I get particularly bored once things are running smoothly. So when we had the whole Gower machinery working we decided to sell to Harper \& Row, which itself was later bought by Rupert Murdoch. ${ }^{53}$ By then I also had an idea for a new type of journal.

\section{Current Opinion}

RP: The Current Opinion review journals?

VT: Right. I could see that while there were a lot of scholarly review journals around they were all rather unsystematic in their approach. So I started two new journals aimed at providing a very comprehensive and systematic review of a subject.

RP: How did that work?

VT: We would take a subject and break it up into its major sections - e.g. cardiology would be divided into hypertension, arrhythmias and so on - and then devote each issue of the journal to one or two of those sections.

Among other things we would create a comprehensive bibliography and then have subject editors highlight articles of special interest - providing a kind of Michelin guide to the most important papers.
RP: Quite a complex process I guess?

VT: Indeed. In fact, when I told my publisher friends what I was doing they said: "This is terrible: you have invented the most cumbersome and complicated way to do a review journal. And you will not be able to charge much."

RP: But you persevered?

VT: I did. Certainly it was a very, very expensive and difficult way to produce a journal. But the end result was just so useful that a lot of people subscribed and we went on to develop a range of Current Opinion journals in medicine and biology, which became very successful and are still published..$^{54}$

RP: In 1996 you moved into web publishing and launched BioMedNet. What was the background to this?

VT: By the time we had put the system in place for the Current Opinion journals, and it was all working smoothly, two things had happened. First, doing them had made me much more interested in the biomedical field and I decided I wanted to do some more biology journals. Second, with the arrival of the Web I became very interested in the idea of developing a community for biologists; one that would appeal both to scientists and to doctors. And since we were very computer literate - we had always had programmers working for us, and technology was part of our culture - it seemed only natural for us to become early adopters of the Web.

So we sold the Current Opinion medical journals to Thomson Corporation ${ }^{55}$ but kept the biology ones; and in 1996 we launched BioMedNet. The aim was to create an online publisher built around a community. ${ }^{56}$

RP: Two years later you sold BioMedNet to Reed Elsevier for a large sum of money. ${ }^{57}$ The service then disappeared from view, and was eventually closed. One publisher I spoke to recently characterised BioMedNet as a good example of how publishers initially misunderstood the Web. "Like the rest of us Vitek got it wrong," he said, but then added: "Unlike the rest of us he made money out of it." Is that accurate?

VT: I don't agree. We are perfectly capable of getting things wrong, and we do get things wrong all 
the time. In fact every single thing we do is wrong - but we keep on changing it until it gets better.

There is a culture here that is very tolerant of mistakes: we hit a wall and we find a passage through; we hit another wall and we find another passage; and so it goes.

RP: So what went wrong with BioMedNet?

VT: The point about BioMedNet is that it was far from finished when we sold it. Consequently it was never proven whether we got it right or not. And the reason Elsevier closed BioMedNet was not because the idea was wrong but because - nonsensically - it did nothing with it.

One of the sad things with selling is that sometimes the buyers don't seem to want to use what they have bought. ${ }^{58}$

\section{Patent Information}

$R P$ : You then turned your attention to patent information. Can you talk me through that?

VT: Sure. An editor from Academic Press ${ }^{59}$ called James Drake approached me and said: "I love the Current Opinion journals. You should do the same with patents." I said: "Ok. Come and help me do it." So we started Current Opinion journals for pharmaceutical patents.

RP: The idea was to apply the Current Opinion template on patent information?

VT: Right. But we soon discovered that it is very hard to create a bibliography of patents. In medicine and biology we were able to extract a bibliography from Current Contents ${ }^{60}$ which lists papers within weeks, and from Medline. ${ }^{61}$ With patents Thomson's Derwent division had an indexing service, ${ }^{62}$ but its fast version was only published every three months (I think), with a few months delay. The main service took much longer.

$R P$ : So you had to rethink what you were doing?

VT: We did. So we did an exercise: we sent people out to patent libraries and had them physically look through all new patents and identify the 150 or so new pharmaceutical patents published every week.

We soon discovered that we could do in a week what it took Derwent months to do. And so we started six print titles - in different areas like cardiology, neurology etc. - and sold subscriptions at $\$ 1,500$ a title. They just flew out of the door and overnight we had a business that was growing really fast.

RP: That of course is how Monty Hyams launched Derwent from his kitchen table in the 1940s! ${ }^{63}$

VT: Exactly. But Derwent had by then become a big organisation and covered all patents. We were small and only interested in the pharmaceutical patents.

After three months, however, Derwent responded by taking three of the six subjects and copying everything we were doing - but charging just $\$ 300$ a title instead of our $\$ 1,500$.

RP: How did you respond?

VT: I went to see the CEO of Derwent and said: "I know you are charging to kill us, but you don't need to sell at $\$ 300$." He replied: "We so admire what you are doing: you are like we were 15 or 20 years ago. But I have to kill you: you are invading our patch - in fact you are trying to mine our gold seam. We must get rid of you as soon as we can."

So we responded by combining all six titles into one, charged $\$ 1,250$ for all of them together, and converted everyone to the single title. Derwent couldn't match it because it was too difficult for them to do six titles. In a short time our business had recovered.

RP: You then developed the Investigational Drugs Database $^{64}$ and Current Drugs Limited, a business you sold to Thomson in 2002 for $£ 85$ million?

VT: That's not quite right, but I don't want to talk numbers. The point is that the culture of our place is that we like to do new things. As soon as something works we try to sell it and use the money to do some other new things. We have done quite a lot of new things that way and we are completely self-financing: we don't borrow from banks, and we have no investors.

\section{Bean counting}

$R P$ : The role you have established for yourself in the publishing industry, then, is one of developing new products and then selling them on to larger publishers? 
VT: Right. These large companies make so much money for so little imaginative effort that they don't try to invent anything, or develop new services. They rely on others to create them. Indeed they no longer see themselves as publishers. I recall once I suggested to Pierre Vinken, when he was head of Elsevier, that as a publisher he ought to do such and such.

He responded: "I am not a publisher: I am a financial institution. I don't work for readers; I work for our shareholders. I have been hired to produce a return."

RP: Bean counting.

VT: Right, as Vinken put it: "Today our business happens to be science publishing, but if science publishing stopped producing a good return we would have to move to something else - because our central objective is to make money and produce returns on our investment. So we are a very big organisation and all our focus is on making sure we are efficient. We make money by cutting waste, so for us to create something is very, very difficult.

RP: So perhaps it was no surprise that Elsevier didn't follow through with your plan for BioMedNet? They don't do innovation?

VT: Yes. One of the great problems with science publishing today is not just that these large companies are very profitable, but they have become lazy. They have just one decision to make each year: how big should their annual price increase be? In other words, how much can they get away with?

There is really nothing else to decide. There is no marketing to speak of - the companies who have a share of the market already have it, and historically have had to do little to keep it. So there is just a little bit of re-jigging here, a little financial tinkering there.

RP: Which is why small innovative companies are so important?

VT: Exactly. Again, as Vinken put it: "That is why we have people like you. You go and start a journal and you are really passionate about it. You think about it a lot, you work like crazy and then you start some other journal and you have five people working on each journal, and you care about those journals.

"Then one day you suddenly start making a profit and you can hardly believe it is possible because until now it was just eating money. What you hadn't realised is that you have been pushing a ball uphill that has accumulated such a lot of value. You just don't know how much money is waiting there to be pulled out of that ball.

"We then come and offer you more money than you can imagine, so you sell it to us. We buy it, and instead of having five people on one journal we have 12 journals for one person, and we cut, and cut, and cut, and this thing starts pulling out an unbelievable amount of money, until slowly the ball starts rolling down the hill, getting smaller, and smaller, and smaller.

"In the process we have extracted lots of money, and we use that money to buy another ball."

\section{Open Access}

RP: You are not just an innovator of course: you are clearly also a very successful commercial publisher. Yet in 1998 you created the first Open Access publisher, BioMed Central. ${ }^{65}$ What intrigues me is why a commercial publisher would become one of the earliest and most committed advocates of OA when it would appear to offer so little financially. In short, why BioMed Central, and why your conversion to OA?

VT: It all began when I visited David Lipman ${ }^{66}$ at the US National Institutes of Health (NIH) for the first time. David is a remarkable man whom I had admired for a long time - he is a great scientist, runs one of the most important bioinformatics institutes (NCBI), is responsible for PubMed, ${ }^{67}$ GenBank $^{68}$ and much more.

While I was talking to David I had an idea that I had been cooking in various vague ways for a while. I said: "I think perhaps the time has come to create a central repository for research papers. The benefits of having everything available in one place, without any access restrictions, would be enormous. Moreover, with the web technology available today publishing can potentially happen independently of publishers. If authors started depositing their papers directly into a central repository they could by-pass publishers and make it freely available."

I added: "I think you are the only person in the 
world who can do it because you have the infrastructure and you have PubMed. So NIH has the means, the technology and the know-how to run a big database like that - I believe you should do it."

RP: How did David Lipman reply?

VT: He said it sounded like a really interesting idea, but it was not for him. "The genome is happening, and we have millions of other things to do too," he said. "Let someone else do it." But a month later he sent me an e-mail: "I can't stop thinking about what you said," he wrote. "I think you are right: we must do something. I am going to talk to Harold Varmus $^{69}$ about it".

RP: This was the seeds of Harold Varmus' proposal to create E-biomed?70

VT: I think so; one of them. During later discussions, however, it became clear that a large funding organisation like NIH could not be seen to be acting as a publisher as there would be a conflict of interest. So I offered to support the repository by starting to publish virtual journals in all areas of biology and medicine, and placing all the articles in the open repository.

RP: That was the origins of BioMed Central?

VT: Indeed. It was proposed, by the way, that all the journals listed in Medline and Embase ${ }^{71}$ could also be invited to deposit their papers in the repository, and that anyone else could start a journal - so long as three people on the editorial board were grantees of major granting institutions. Initially we also thought that preprints could be included too. Authors would post their papers and there would be a filter to check the system was not being abused.

RP: The filter system sounds like the model proposed by Paul Ginsparg ${ }^{72}$ - a concept he developed after creating the physics preprint server ( $\left.\operatorname{ar} X_{i v^{73}}\right)$ in the early 1990s?

VT: Yes, a system like that. Pat Brown ${ }^{74}$ had also become enthusiastic about such a model, and his ideas on pre-prints were an important influence on all of us. "If physicists can publish preprints then why do we need referees, who just mess papers up," he argued. "Why don't we just publish preprints and get them refereed afterwards?" Paul was also involved in the discussions, and he became a close friend. It turned out, however, that the subject was much more complex, much richer, and with so many aspects that we hadn't thought about.

RP: And as a result of this complexity when the NIH repository was eventually launched as PubMed Central in 2000, it included peer-reviewed papers only, with no preprints?

VT: Right. Also a little later Pat Brown, Harold Varmus and Mike Eisen ${ }^{75}$ sent out the Open Let$\operatorname{ter}^{76}$ that started the Public Library of Science. Lots of people signed the letter. There was a great swell of opinion for this new way of publishing research results, which later became known as Open Access. It seems there was a lot of anger about the greediness of publishers.

\section{Inevitable}

RP: You too are a publisher of course.

VT: True, but for me the rights and wrongs of making profits from science publishing was never at issue. After all, it's the legitimate job of commercial publishers to make profits, and I see myself as one of them.

For me the issue has always been simply that both science and society will greatly benefit from $\mathrm{OA}$, and that it offers an exciting new commercially sustainable model of science publishing that I wanted to experiment with.

RP: Do you think the development of the Web means that $\mathrm{OA}$ is in any case inevitable?

VT: I think so. But it is not just that the Web has made it possible: biomedical science simply can't function efficiently any more without open, unrestricted access to research results. Access to past findings is of the essence in doing science, and research is becoming more data rich, so that the results it produces are increasingly database like.

We are seeing, for instance, research papers containing databases and being linked to databases, and it is becoming simply impractical to work without the ability to easily gather and manipulate the data.

RP: And this data now needs to be free?

VT: Well, we have seen from our experience with 
the genome how important it is that the data is free and that everyone can access it. ${ }^{77}$

What this means is that we have to completely re-think the way science reports its findings, including the basic idea of the paper and why is it written. The whole area is changing very quickly, and this surely is a big challenge to science publishers as well as to scientists. But just think how many businesses grew up around the genome, and how many inventions have been made because the data is all in one freely available database and people can gather it and play with it.

\section{The challenge}

RP: So publishers have little choice but to embrace $\mathrm{OA}$. The challenge lies in creating a business model capable of supporting Open Access publishing?

VT: Right. When we started BioMed Central we didn't know what the business model would be. We believed the data would have to be free, but it also became clear that - for the moment at least - authors couldn't place their papers in the public domain without some processes that cost money. What was also clear was that authors are more interested in publishing than readers are in reading. We also knew that authors have always been prepared to pay for having their papers published by paying page charges and paying for colour pictures etc.

$R P$ : Which means that there remain plenty of services for publishers to provide?

VT: Exactly. So we said: "OK, we will turn the current model upside down and offer the research articles free to readers and charge for services to authors, rather than charge readers via subscriptions. We will take their papers, mark them up, find referees to review them, and generally act as an intermediary."

Of course the charges are not really to authors personally, but rather to the funders of the research or the institutions where the authors work. We soon realised that such a business model could be very effective.

RP: Currently, however, neither BioMed Central nor the Public Library of Science makes money, and some maintain that $\mathrm{OA}$ publishing will never be financially viable. When you gave evidence to the UK Select Committee into scientific publishing ${ }^{78}$ you said that you expect to be in the black sometime in 2006. Is that still the plan?

VT: Yes. We think we need about 2,000 to 2,500 papers a month to break even. We estimate that we will have around 2,000 by the end of next year. ${ }^{79}$ While OA publishing will never be as profitable as the current system of selling subscriptions we are confident it can and will be profitable. ${ }^{80}$

RP: One of the problems you face is that authors appear to be as reluctant as publishers to adopt OA.

VT: You are completely wrong to say that. In fact, $\mathrm{OA}$ is growing much faster than anything I have ever experienced in my time in publishing, and it will continue to grow very fast as more and more people find out about it.

RP: Can you give me some figures to demonstrate that?

VT: Absolutely. Submissions to our journals are now running at above 700 papers $^{81}$ a month. A year ago this figure was 300; two years ago it was about 120 . So it is more than doubling each year. We know that authors who have published Open Access once publish that way again. And they tell others. Today around $1 \%$ of papers are published OA. I believe that when this becomes more like $5 \%$ we will reach a "tipping point". Suddenly everyone will start knowing someone who has done it and for whom it worked well, and at that point the rate of growth will increase rapidly.

\section{Better than nothing}

$R P$ : Of course if authors are mandated by research funders to adopt OA they will have little choice but to embrace it. The proposal to require that all NIHfunded research is made freely available in PubMed Central was significantly watered down. In its final version the proposed delay from when a paper is published and made freely available was lengthened from six to 12 months, and what was initially a requirement became merely a recommendation. What does this portend for the success of $\mathrm{OA}$ ?

VT: The final proposal is not ideal, but it is better than nothing. ${ }^{82}$ However, the point is that $\mathrm{OA}$ is inevitable, and the principle is now so broadly 
and generally accepted that funders feel obliged to do something. Many governments do too: the US Congress, for instance, seems to feel as strongly about the issue as the NIH does. ${ }^{83}$

Clearly, however, we are going to go through a period of transition; and we will see a number of different approaches co-existing. In some cases it will be a requirement that papers are made $\mathrm{OA}$; in others it will be a recommendation. Likewise, in some cases it will happen immediately; in others there will be a delay.

But what the NIH has done, what the Wellcome Trust has done, ${ }^{84}$ and what we expect research funders in the $\mathrm{UK}^{85}$ and France to do, ${ }^{86}$ is just an intermediary stage.

Within a year or two we will see that all publicly-funded research will be made immediately available on the Web, and people will be able to do whatever they want with it - so long as they acknowledge the source.

RP: One further complication that could perhaps retard progress is that the OA movement has forked, with advocates disagreeing over the best way forward. While OA publishers like you advocate OA publishing (the so-called "Gold Road" to OA) supporters of the "Green Road" like Stevan Harnad argue that it is sufficient for authors to continue publishing in traditional subscription-based journals, but to then self-archive their papers. Does Harnad have a point?

VT: I do not think so. Self archiving is of course very desirable, but the issue is quite simple: publishers are not really going to allow authors to selfarchive in an easy way, and authors are not going to do it unless it is completely painless.

RP: I'm told that around 93\% of journals currently do allow self-archiving? ${ }^{87}$

VT: They say they allow it, but publishers have merely created the pretence of allowing it. They don't really. They say they allow self-archiving, but authors can't just take their published papers and archive them: they have to use their original manuscript, without any of the corrections and changes made by the publisher. They have to mark it up themselves, and they cannot use the illustrations created or amended by the publisher. In practice it is really quite difficult to reproduce the published paper.
If self-archiving were so easy why isn't it happening? Because in practice self-archiving is impractical. That said, for those who want it BioMed Central supports self-archiving by offering to help institutions create repositories for their researchers' papers. ${ }^{88}$

\section{Ideology}

RP: If I understand correctly, you are saying that embracing OA is simply an issue of commercial pragmatism for publishers. But I wonder if there is an element of ideology at play here too. The president of Blackwell Publishing ${ }^{89}$ Bob Campbell, ${ }^{90}$ for instance, described the UK Government's refusal to mandate $\mathrm{OA}$ as a triumph of "common sense over ideology"? ?1

VT: Bob is a traditional publisher. For him OA is bad news as it threatens his particular business. If there is any ideology here it is Bob's business ideology. It is OA that represents common sense. Undoubtedly there are many who support the present system. That, however, doesn't mean that it is the best system. I am sure there were objections when they introduced the automobile.

RP: So it's a case of "They would say that wouldn't they?"

VT: It is. Indeed, if I were running one of these companies I too would be doing anything to prolong the status quo for another year; and I would invent any argument - no matter how idiotic - to prolong it.

What is sure is that those who criticise authorpays Open Access publishing are simply fighting a rearguard action. The reality is that the subscription model of publishing cannot survive: the moment libraries don't need to have their own collections, and one copy of a paper is enough for everybody, the subscription system just has to collapse.

RP: Commercial publishers may simply choose to exit the market if their profits start to fall, but what about learned societies? They are more vulnerable aren't they?

VT: Learned societies have climbed on the bandwagon of the money-making scheme that publishers invented. In doing so they started to act against the interests of their members. This has created large ineffective and inefficient bureaucracies like 
the American Chemical Society (ACS) ${ }^{92}$

In most cases it isn't the society as such that doesn't like it - it is the bureaucracy of the society. This is not surprising: the reality is that lots of people's jobs will go. That is why they don't like it.

RP: So what will happen to societies?

VT: They will revert to doing what they did before the bandwagon came along. They will continue to exist, and to the extent that their members want to be served they will pay and be served.

But you know there are lots of societies that don't publish journals for excessive profit. And let's face it, those societies that do publish journals for excessive profits are taking money out of science, and they are taking money out of their members.

RP: The former editor-in-chief of the ACS's Chemical EF Engineering News Rudy Baum would undoubtedly disagree with you. He also smells ideology, arguing that the "unspoken crusade" of the OA movement is to "socialise all aspects of science". ${ }^{93}$ In an attempt to find out if you have any ideological agenda I asked Tim Hailstone about your politics. He said, "Vitek believes politicians should be kept out, that is why he is in favour of coalition governments. Anything that controls their power." Is that right?

VT: It's true that I am not a political person, and I have never belonged to any political organisation. Indeed, I suspect ideology. After all, I came from Poland - a country that experienced the consequences of ideology. I don't like ideologies, and I am worried about ideologically motivated politicians, which is why I like coalitions. Coalitions help to curb ideologies.

RP: But you do clearly see a role for government? VT: Of course. Politics and politicians play a very important role in societies. They keep society going: they take care of people who are in trouble, and create a healthy environment in which people can flourish. So politics are necessary, but ideology isn't. The job of politics is much better undertaken by people who are pragmatic, and through a process of compromise.

\section{Not interested in money}

$R P$ : So what primarily motivates you is money is it? VT: No. Actually, I am also not interested in money particularly. I am not one of those people who said to himself: "I want to be a millionaire by the time I am forty." I am perfectly happy not to have money, although it is nice to have it. What I enjoy is working with this group of people, and inventing new things; things that were not there before; and things that are both difficult to do and complicated. After all one of our goals in life is to do something interesting, to avoid boredom at all cost.

RP: Nevertheless, much of what you do appears to be financially motivated. I'm told, for instance, that you have taken up art collecting and that this for you is not so much a matter of having beautiful paintings but another opportunity to make money?

VT: I am not an art collector.

RP: A dealer then?

VT: I am not a dealer.

RP: You do buy paintings, and your office here is full of catalogues from Sotheby's and Christie's?

VT: You know once you buy a picture they start sending you these catalogues. They have nice pictures to look at, so I put them in my bookshelf!

But listen, I am not a dealer. In fact, I am completely not interested in dealing; and I am not interested in collecting.

RP: So why do you buy paintings?

VT: I will tell you what I do with art: I will sell a company and will as a result have a lot of money. We then use that money to develop something new. Sometimes we have a lot of money, and since I never invest in anything, and I don't buy shares, rather than just putting the money in the bank I take some of it and I buy a few pictures.

Often a project will come to almost nothing, and so we have to sell something else - and twice I have had to sell paintings to raise some money.

$R P$ : I guess your most significant personal investment would have been the house you had built in Barnes. ${ }^{94}$ This has an unusual design I'm told - all based around the concept of the triangle? 
VT: The background to building the house is that when I sold Gower to Harper \& Row the president of the company decided that he liked me. So he asked me to stay. "We are going to change Harper \& Row," he said. "And you are going to help me."

I very quickly realised, however, that nobody in the company wanted any change, least of all the president. It was just words. Then after working there for about nine months or so I met the president in Frankfurt and he asked me what I thought about the company. "I think it is terrible," I said.

"Why do you think that?" he asked; to which I replied: "I have to tell you that you are the reason. You are just a terrible head of the company. You are obsessed about things, and you hide away."

\section{RP: How did he react to that?}

VT: After a short hesitation he said: "You know, you are very good at strategic thinking but your tactical judgement is really quite bad. So I am asking you from this moment to take one year's sabbatical - on full pay - and just do what you like, only don't compete with us. One year from now we will meet and in the interim I will ask you to think about just one subject: 'Harper \& Row in year 2000 (this was in the 80s)."

So I took the year off and built a house - after all, everyone dreams of building a house one day.

RP: So why the triangles? Everything, including the door handles, I'm told, is triangular?

VT: I studied architecture for a year and I am amateur designer. I am also a mathematician - or used to be - and I like those sorts of games where you make patterns around triangles and squares. So I thought: "What is a house? [Starts drawing a sketch on a piece of paper to demonstrate] A house is a square in a triangle; and then there is an arch, a chimney and a door."

I played with this idea and I drew it on a pattern of squares and triangles. It turned out that the design made a very nice house!

\section{Profound transformation}

RP: Looking to the future, how do you see science publishing developing over the next ten years?

VT: It will go through a very profound transformation. In fact, we will hardly recognise it ten years from now. It will become less dependent on things like peer review and selection, for instance, and it will become a much more seamless and continuous process.

RP: Can you say a little more about this transformation?

VT: Science is about finding what and how things happen and making these findings visible. It is made up of two things: the findings themselves and the interpretation of these findings. A good example is a clinical trial: somebody takes a group of patients, gives half of them this, and half of them that, and then compares the results. They then have the data and they make their interpretation of that data, which they publish. Others then can interpret the data differently.

Today what we mostly see is the interpretation of the data: the data itself is not published. I think the data will become more visible and people will share the data in the way they did with the genome.

In the future, therefore, the interpretation of the data will be attached to the data, and as a consequence, the whole process of peer review will increasingly be seen to be irrelevant, ineffective and too time consuming. In practice, it will simply not be done.

RP: A lot of papers will never be peer-reviewed?

VT: Yes, I think Pat Brown's call for publishing without prior peer review will come true, and making the data visible will become the single most important thing. People will publish the data and the interpretation of the data and there will be de facto post-publication refereeing of papers - done by various bodies for various reasons.

RP: And the very concept of "the paper" starts to seem outdated perhaps?

VT: That's right. When we talk about papers we are imprisoned by the idea of something that consists of a discrete quota of information, mandated by the fact that there is only so much you can do on paper.

In future a "paper" could be one sentence long or 1,000 pages long, and it will be constantly accumulating. You don't really need publishers for that: 
you need tools, and software development.

RP: What then will this transformation mean for traditional publishers?

VT: It doesn't matter what it means for publishers. It is not written in the stars that we have to have science publishers; and it is not a moral imperative for us to defend them. Science doesn't exist for publishers: publishers are there to serve science - so if there is something for them to do they will do it. But as I say, while science publishing faces a crisis today I believe there is a very big role for publishers in the future.

\section{$R P$ : How do you mean?}

VT: It is not practical for scientists to do anything that requires a strong editorial overhead - so all the things scientists cannot do themselves will need publishers. Review journals for instance. Above all, however, I believe it means highly specialised editorially intensive databases.

So where today you have thousands of journals sold on subscriptions, in ten to twenty years there will be thousands of editorially intensive databases also sold on subscriptions, many of them probably sold by existing science publishers.

$R P$ : You are saying that subscription remains a viable model for the future?

VT: I cannot think of a better model.

\section{Not everything has to be free}

RP: How does that fit with the principles of Open Access? If science requires that research be freely available, subscriptions will surely work against that by limiting access?

VT: Not everything has to be free: the original research findings must be freely available to all because you can't do science without research findings - and the author's papers must also be freely available.

RP: So we are talking about three different types of information here: the primary research data, ${ }^{95}$ the research papers in which these findings are reported and interpreted, ${ }^{96}$ and value-added databases that take these first two types of information and add value to them. The first two types of information will be openly available, but the last will be sold on a subscription basis to researchers?

VT: Right. A value-added database would effectively surround publicly available information, and would include commissioned analysis and synthesis of that information. It would also structure the data and arrange it so that it would provide a useful tool for researchers.

RP: Can you give me an example of how this might work in practice?

VT: Sure. A publisher could, for instance, focus on the bit of the carrot genome that makes it red. This could involve collecting all the papers written about that part of the carrot genome and then commissioning someone to write a commentary on those papers. This would synthesise the papers and explain their significance to that bit of the carrot genome. Then all the data - including the raw source data, the published papers evaluating that source data, and the commissioned commentary - would be structured in some electronic format designed to make it easy for researchers to use, to display, and to link to other relevant databases. It would also be constantly updated.

RP: And this value-added database would be proprietary, and would be sold on subscription?

VT: Yes.

RP: Presumably unlike OA research papers - which OA publishers make available under a Creative Commons licence - these databases would be subject to traditional copyright terms?

VT: Right. In this respect they are like textbooks. It is the part that the scientists cannot - or will not - do for themselves. However, someone will need to invest in them, to commission the commentary, and to develop them. And so it is logical that publishers should do this, and that they should charge researchers for doing so.

RP: So the Open Access author-pays business model is only relevant in relation to the activity of helping researchers make their papers freely available on the Internet?

VT: Yes. Open Access is a service not a subscription allowing access. Moreover that service will become 
a smaller and smaller component of the publishing business. More and more of what we do for authors today they will be able to do for themselves in the future, and as we develop more tools to allow them to do it themselves, so what we charge them will be less and less.

RP: OA publishing, therefore, is likely to prove a shortterm business opportunity for publishers. The future lies in providing value-added databases?

VT: I think so. However, we publishers must remember that the issue is not what is good for publishers but what is good for science. It is neither in the interests of funders nor of authors not to embrace OA. It is only in the interests of traditional publishers to continue the status quo. If some publishers find that there is no money in publishing they will do something else. The central point in the Open Access debate is that it is essential for science and beneficial for society. That is what makes it inevitable.

\section{We believe it is worth doing}

$R P$ : I just want to return to your motivation for supporting OA. From your perspective BioMed Central is no different from any of your other businesses right? There is no politics, no ideology; it's just another business?

VT: We are a start-up shop, or incubator, so everything we do is different. We have an incredible amount of very talented people - and lots of young people - and we do what we do with passion and pleasure. Indeed, everything we do we do because it is something we believe is worth doing, both financially and as a general good.

But if you ask me directly what my motivation for promoting $\mathrm{OA}$ is I will answer that it is twofold: firstly, it is a very interesting, complicated and difficult thing to achieve; secondly it is good.

RP: Good?

VT: It is good for science. It is a good thing.

RP: Good is an interesting word to use. It implies an emotional commitment on your part.

VT: Why do I use the word good? That's a good question! It may not be an appropriate term: it is not quite right to say science is good. But I am on the side of science - because it is rational; it is human; it is understandable; and it is beautiful.

So while I like movies and pictures and such like, I believe in science. It is a great expression of humanity; at the same time it can benefit humanity. That is why I say it is good.

So what helps science evolve faster and better especially the biomedical sciences (which can help us better understand what is happening in our bodies and in nature) - is in my view good.

RP: So OA promises to make science better?

VT: OA will increase the efficiency of science, yes. What also motivates me, by the way, is that most of my friends are scientists now. I love them and feel attached to them; they are part of my community and part of my work - if I can make some money in helping them so much the better.

RP: Is there also an ethical component here?

VT: Yes. I think there is. If something is beneficial to society, and it can be done, then it should be done. As a result of the Internet, for instance, things that before were desirable but not possible are now possible. And since OA is beneficial to society then there is an ethical reason for insisting that it happens. This ethical dimension operates on some people more than others. Personally I am passionate about Open Access, and it means a lot to me.

\section{Changing the texture of businesses}

RP: Do you see any connection between Open Access and the growing number of other "free" and "open" movements like the Free and Open Source Software Movements, Creative Commons, Open Spectrum, Open Biology etc.?

VT: Yes. I do. I think there is an ethical component common to all of them. If something that was not possible before is now possible, and if it is desirable for society that it should happen, then there is an ethical reason for making it happen.

RP: And businesses just have to adapt?

VT: Exactly. The point is that what the Web is doing is changing the texture of businesses in a very broad range of ways, because it is making things possible that were not previously possible. Like 
animals in the jungle, businesses will just have to adapt, or move elsewhere.

RP: Could it be that our basic understanding of economic models may also have to change? That the economic rules of the past may be being completely re-worked?

VT: It is certainly possible. I do have a sense that something very deep and very profound is happening in the way in which information is exchanged. So it would make sense that the economics of information may be changing too.

But I am not a thinker in that sense. I am not a philosopher. My forte is finding some really interesting, difficult and worthwhile problem to solve and then to try and execute it.

RP: The high regard you have for the rational, and your distrust of ideology: this presumably stems from your childhood? I'm told, for instance, that when the war started one branch of your family opted for the Germans and the other side for the Russians - two ideologies in conflict. Those of your family who opted for the Germans were all killed weren't they?

VT: Like many people in such families when the war broke out my parents decided to run away from the Germans. Actually, they ran away because they were communists. But most of the family my grandparents and all my uncles and aunts - all believed that the Germans would be better than the Russians.

When the Germans arrived, however, everybody was killed immediately - within the first week. Practically every single one was killed; few survived.

RP: This was in the Jewish shtetl your family came from?

VT: Yes.

RP: All this must have had quite an impact on you?

VT: For a Jewish family living in Eastern Poland/ Western Russia this was typical story.

RP: You say your father was a communist. He embraced an ideology then?

VT: My father remained a communist until 1956, when Khrushchev ${ }^{97}$ came to power and sent the
Red Army into Hungary. ${ }^{98}$ At that point my family very courageously woke up and realised something was wrong.

I genuinely believe that my father was a believer, and that he lost his belief at that point. He left the communist party and asked to emigrate to Israel, which put him and his family in great danger. After a long time he was finally allowed to go.

\section{Chance and personality}

$R P$ : What I'm trying to explore is the extent to which your childhood experiences influenced the way you have led your life, and developed your career?

VT: Actually, I see no direct relationship. I think such things are a mainly a product of chance and personality. You are what you are because of your genes; and to a large extent you come across things by chance. Then, when you are faced with events, you make choices.

RP: You have over the years taken an interest in the humanities, in the arts and in science. Most of your entrepreneurial activities, however, have been devoted to science. Is that because there is more money to be made in the sciences, or is it - as I think you were indicating earlier - because you believe the sciences are ultimately more important?

VT: No. Again, it was just circumstances, like everything in life. You, for instance, are a journalist doing this interview. That is not, I suspect, because you think it is the single most important thing in life, but because that is how things turned out: circumstances led to you becoming a journalist; you found yourself doing it, and it was quite enjoyable, and you said: "Well I will do some more of it."

Suddenly you found yourself quite good at it. So it was for me. It was just chance. That said, I enjoy what I do very much.

$R P:$ No regrets then?

VT: Absolutely not. I love what I do, and I think science publishing has turned out to be much more interesting than making movies. In fact it is incredibly interesting now because science publishing faces a big crisis, and what is a crisis for some is an opportunity for others.

I also think science publishing will be bigger, more important, and more exciting in the future 
than it is now - because there will be more science, and because scientists need lots of services. It is just that they don't need the particular service publishers have been providing quite as much as before.

$R P: O k$, thank you very much for your time.

This interview is published at http://poynder.blogspot. com/2006/05/interview-with-vitek-tracz.html under the terms of the Creative Commons Attribution-Non-commercial-NoDerivatives Licence (http://creativecommons.org/licenses/bync-nd/2.5/). Richard Poynder would like to acknowledge the help of the Open Society Institute, which provided a small upfront grant to enable him to get started on The Basement Interviews Project. Further information about The Basement Interviews can be found at the Open and Shut? site.

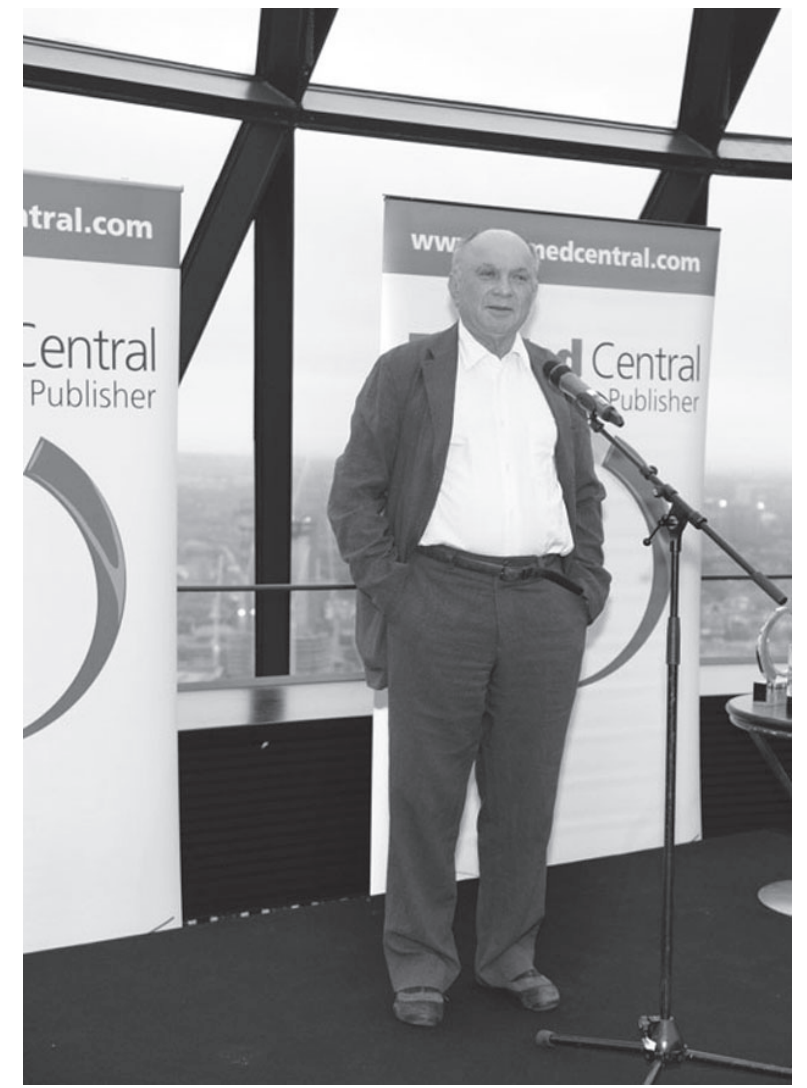

BioMed Central Founder Vitek Tracz addresses the audience at the 4th Annual Research Awards in London, June 2010. 


\section{In Retrospect: Vitek Tracz in $\mathbf{2 0 1 0}$}

It is six years since I spoke to Vitek Tracz about BioMed Central and Open Access. What has changed in the intervening years?

A lot has happened, but it remains unclear when OA will become the norm for scholarly communication, or indeed what an $\mathrm{OA}$ world will look like.

Without doubt the most significant event came in October 2008, when Tracz sold ${ }^{99}$ BMC to Springer (for an undisclosed sum). This reaffirmed Tracz as the serial entrepreneur he always claimed to be, and provided him with his desired exit strategy.

For Springer it was an opportunity to leapfrog its competitors and become the world's largest OA publisher with a stroke of the pen.

And for the OA movement the deal was a huge fillip: If the world's second-largest commercial journal publisher was now prepared to wade knee deep into $\mathrm{OA}$ waters, $\mathrm{OA}$ advocates argued, the oft-repeated claim that OA publishing is not financially viable had finally been laid to rest.

Above all, however, it was a big win for OA publishing (Gold $\mathrm{OA}$ ); ${ }^{100}$ and, by implication, for Hybrid $\mathrm{OA}^{101}$ too. An intermediate form of $\mathrm{OA}$ pioneered by Springer with Open Choice ${ }^{102}$ in July 2004, Hybrid OA allows researchers to continue publishing in subscription journals, but to opt to pay an article-processing charge (APC) ${ }^{103}$ if they want their paper to be freely available on the Web.

Ironically, while it was initially intended to call OA advocates' bluff - by challenging researchers to "put their money where their mouth is"104 - Open Choice was later re-imagined as a strategy to help publishers migrate their subscription journals to an $\mathrm{OA}$ environment in an orderly fashion.

Despite its origins, therefore, in retrospect Open Choice looks like a canny move by Springer; even more canny perhaps than buying BMC.

Why? Because as self-archiving began to grow it became increasingly clear that if publishers sat on their hands while funders and research institutions introduced self-archiving mandates ${ }^{105}$ (Green OA), ${ }^{106}$ then their profits would undergo slow, inevitable decline. Sooner or later, after all, there would be a sufficient number of papers freely available on the Web that libraries would be able to cancel journal subscriptions.

If, on the other hand, publishers were able to offer Hybrid OA they could not only deny that they were standing in the way of progress, but might be able to lock in their current revenues and port their traditionally high profit margins to the new publishing environment.

\section{Penny dropped}

As the penny dropped publishers began falling over themselves to introduce Hybrid OA options like Open Choice. In the process, OA publishing was transmuted from bogeyman to life raft, and publishers' lobbying activity began to focus exclusively on opposing Green OA.

Certainly the threat of Green OA is real. As it has gained mindshare so it has also acquired teeth. Significantly, six months before the sale of BMC, in April 2008, the US National Institutes of Health (NIH) had strengthened its Public Access Policy ${ }^{107}$ (first introduced in May 2005 as a recommendation), to make it compulsory rather than voluntary for NIH-funded researchers to make their papers publicly available.

This has seen a rapid growth in the number of NIH-funded papers available outside publishers' paywalls, and so was a big win for Green OA.

Given the importance of the NIH, and the now visible success of its Green OA initiative, the NIH Public Access Policy has become a symbol of all that is good or bad (depending on your point of view) about OA, and a target for lobbyists on both sides of the OA debate. Amongst other things, both sides have sought support for their cause from US Congress.

OA advocates, for instance, have sought to have the NIH Policy extended to other US government agencies - most notably by lobbying for the Federal Research Public Access Act (FRPAA). ${ }^{108}$ While the first iteration of the FRPAA died in committee a new version was introduced $^{109}$ in September 2009.

For their part, publishers have pushed for a very different kind of bill - the Fair Copyright 
in Research Works Act (FAIR). ${ }^{110}$ Rather than propagating the NIH Policy, FAIR would repeal it. This bill too failed at the first attempt, but was also re-introduced ${ }^{111}$ in 2009 . Were FAIR to succeed it would be a huge blow for Green OA.

(For insight into the arguments for and against Green OA readers could do worse than review the arguments ${ }^{112}$ made by both sides of the debate at a US House of Representatives subcommittee hearing on FRPAA in July 2009).

\section{Split}

Publishers' appropriation of Gold OA has been accompanied by a growing split in the OA movement, with many questioning where they should be putting their efforts today. Some argue that since all varieties of $\mathrm{OA}$ - Green, Gold and $\mathrm{Hy}$ brid - hold out the promise of OA, all should be supported.

Others insist that Green OA should be the priority. Not only can it deliver universal OA much more quickly than Gold, but it would enable the research community to free itself of the so-called serials crisis - an inflationary spiral in journal subscription prices that has bedevilled libraries for decades now. This is all the more necessary, Green OA advocates argue, given that these high subscriptions enable publishers to earn excessively high profits from the public purse.

It is worth noting that librarians became active supporters of $\mathrm{OA}$ primarily because they assumed OA publishing would provide a more cost-effective way for scientists and scholars to communicate their research to one another. Over time, however, it has become clear that this is highly unlikely. APCs have risen at least as fast as traditional journal subscriptions. When BMC launched ten years ago, for instance, it charged just $\$ 525$ to publish an article. Today, BMC charges $^{113}$ between $\$ 740$ and $\$ 2,380$ per paper. Hybrid OA is even more expensive, costing from $\$ 3,000$ per article to publish under Springer's Open Choice scheme or OUP's Oxford Open, ${ }^{114}$ to $\$ 5,000$ to publish in Nature Communications $^{115}$ or one of Elsevier's Cell Press ${ }^{116}$ titles.

In an interesting development in June 2009,
Springer launched SpringerOpen ${ }^{117}$ - a new division that will produce a range of Gold journals. Publishing in a SpringerOpen journal will cost less than half what it costs to publish under Open Choice (i.e. $\$ 1,025$ to $\$ 1,280$ ), but these will be new journals without a track record. Besides, most publishers now expect the future business model to rest not on APCs, but on "open access membership" schemes, and SpringerOpen journals will be rolled into BMC's membership scheme. ${ }^{118}$

What is open access membership? Conscious that the individual researcher may not have the necessary funds to pay APCs, OA publishers have persuaded many libraries to bulk purchase APCs (or APC discounts), by means of "membership" schemes - thereby ensuring that publishing is free at the point of use for researchers at member institutions. Essentially these schemes are subscriptions by another name; and like subscriptions they have shown themselves to be highly susceptible to price inflation. As Susan Klimley, a librarian in the Health Sciences Library ${ }^{119}$ at Columbia University, pointed out ${ }^{120}$ last year, BMC's membership fees have risen by $8 \%$ a year. And in 2009 the increase was 10\%.

Weeks after the launch of SpringerOpen the company announced ${ }^{121}$ it had signed an agreement with Germany's largest scientific organisation, the Helmholtz Association. ${ }^{122}$ This will provide OA membership to the sixteen research centres of the Association and will cover publication costs for both SpringerOpen and BMC journals.

At the same time universities are starting to move seamlessly from a subscription model to a membership model. Again, Springer has taken the lead here. In 2009, for instance, it entered into an agreement ${ }^{123}$ with the University of California in which "articles by UC-affiliated authors accepted for publication in a Springer journal beginning in 2009 will be published using Springer Open Choice with full and immediate open access."

The problem, of course, is that in signing these agreements publishers will aim to maintain their current revenues, so any savings made possible by 
OA will not be passed on to libraries.

At heart, the argument made by Green OA advocates is that while Gold and Hybrid OA may eventually solve the access problem, it is highly unlikely that they will ever solve the affordability problem confronting the research community. If, by contrast, self-archiving is prioritised publishers will be forced to reduce their prices rather than increase them - since self-archiving will trigger the journal cancellations needed to persuade publishers to do so (by downsizing if necessary). As a result, the research community will regain control of scholarly communication, and will no longer be at the mercy of constant price inflation.

Publishers in their turn argue that if the research community wants $\mathrm{OA}$ it should embrace Gold and/or Hybrid OA. And since most if not all subscription publishers now offer Hybrid OA there is no reason not to. Consequently, they add, Green OA is simply not necessary. Moreover, in threatening publishers' financial stability self-archiving risks destroying the entire scholarly communications infrastructure.

To the dismay of Green OA advocates, more and more in the research community are beginning to be convinced by the publishers.

Currently, therefore, we are witnessing what amounts to a race; one whose outcome will depend on whether a sufficient number of papers become freely available before Gold and Hybrid $\mathrm{OA}$ acquire sufficient mindshare amongst the research community that they come to be viewed as the only practical way of achieving OA.

As I put it" ${ }^{124}$ last year: "If Green OA wins the race, the research community can hope to finally free itself of both the access and affordability burdens that have for so long dogged it, and publishers will be forced to give up some of their profits. The research community will have won the war. However, if Gold OA wins the research community will have freed itself of the access burden, but failed to free itself of the affordability burden. Publishers will have won the war."

Who will win this race? We don't know. What we can say is that the battle for Open Access is far from over, and how that battle ends will deter- mine what OA eventually looks like, and whether the research community is able to free itself of the constant price inflation that has for so long burdened it.

\section{Demise}

How Tracz is viewed through the lens of history will doubtless also depend on how the drama plays out.

If Gold OA wins Tracz will likely be portrayed as the canny publisher who masterminded the strategy (Gold OA) that saved publishers' bacon, and allowed them to re-locate to the new publishing environment without having to surrender their high profit margins.

If Green OA wins he will be the wily entrepreneur who - in the nick of time - sold an unsustainable publishing business to a large competitor.

To do Tracz justice we should note that while most discussions about OA today invariably assume that we still live in a print world, Tracz never made that mistake. Those reading what he said to me in 2004 cannot but conclude this.

As he put it, "When we talk about papers we are imprisoned by the idea of something that consists of a discrete quota of information, mandated by the fact that there is only so much you can do on paper. In future a 'paper' could be one sentence long or 1,000 pages long, and it will be constantly accumulating."

For that reason, he told me, OA publishing should be viewed as a short-term business opportunity. "Open Access is a service not a subscription allowing access. Moreover that service will become a smaller and smaller component of the publishing business. More and more of what we do for authors today they will be able to do for themselves in the future, and as we develop more tools to allow them to do it themselves, so what we charge them will be less and less."

Significantly, he added: "You don't really need publishers for that: you need tools, and software development."

In other words, the Internet not only implies $\mathrm{OA}$, but the demise of the traditional journal, and the demise of the traditional publisher as well. 
That is a very different picture to the one painted by most OA advocates today. The danger, however, is that if publishers succeed in their aim of porting the traditional journal to the Internet (along with its print-age costs) they will have imposed an out-dated industrial model on a medium that promised so much more - purely in order to protect their profits, and at the expense of the taxpayer.

Here we could usefully listen to Tracz again: "It is not written in the stars that we have to have science publishers, and it is not a moral imperative for us to defend them."

On the other hand, if financial analysts like
Sanford Bernstein's Claudio Aspesi are correct to argue that the current global financial crisis will have a very significant impact on research institutions' budgets (http://poynder.blogspot. com/2010/06/reed-elsevier-need-for-progressive. html) then publishers' hopes of migrating to an $\mathrm{OA}$ environment with their profits intact are likely to be dashed, regardless of the take-up of Green OA. In such a situation all bets are off for, as Tracz points out today (see below, Tracz today), what publishers can charge for scholarly communication "in the end will depend on what the whole system is prepared to pay". Or, in Aspesi's terms, what the system is able to pay.

\section{Tracz today}

But where does Tracz stand on these issues today? Does he still believe OA publishing is a short-term business opportunity? Does he still support OA? Or did his interest evaporate as soon as he had Springer's cheque in his hand?

Speaking to me by phone from Paris in September, Tracz reminded me that OA was never about money for him. It was, he insisted, always an ethical issue before it was a financial one. "I took horrendous risks, and I was not at all sure that it would ever make financial sense. It was an ethical issue, and I was intrigued by the complexities of it."

For that reason, he says, he takes particular pride in having demonstrated that OA publishing is sustainable, and that he encouraged other publishers to embrace it as a result. "We now know that $\mathrm{OA}$ is feasible, it is practical and it is possible."

On the costs of OA publishing, and the role of publishers, however, his views have shifted a little. What he discovered, he says, is that OA publishing requires a similar amount of work as traditional publishing. For that reason, he adds, "there is still a need to help researchers make their findings visible, and so there remain continuing opportunities for publishers - who will continue to make money from scholarly publishing."

Does he think that OA publishing will prove more or less expensive than traditional publishing? "I always assumed that OA publishing would be cheaper," he replies, "but OA publishing is more complicated than we had initially envisaged. The logistics of it all quickly becomes very complicated, so it turns out not to be much cheaper than traditional publishing. This in turn means that the amount of money publishers can make is similar."

He adds: "You know, it never really mattered to me whether OA publishing would be more or less expensive. I never saw that as the key question. Even if it turns out to cost more than traditional publishing I don't mind, because the need to have unrestricted access to science is so important. It is important for science; and it is important for societies to see what is happening in science. So the price is not important."

I reminded him that the research community has long argued it cannot continue to pay the prices that publishers demand for disseminating research indefinitely. If OA publishing is not cheaper, I suggested, society has a serious problem.

"I have never participated in the economic argument," he replied. "I haven't got the faintest idea how that works, who says it is too much, on what basis they say it, or where it will all end. But it doesn't matter that I don't know."

And it doesn't matter, he explains, because if there is a problem with pricing the market will find a solution. "It's no different to when you walk into a market to buy a picture: If the buyer is not prepared to pay the asking price then the seller has to reduce the price. The price will always find its natural level. It's as simple as that. So in the end it 
will depend on what the whole system is prepared to pay."

I asked if Tracz is still actively involved in the OA movement. "I have never been part of any movement, or group, and I take no interest in the different flavours of OA," he replied.

Then he added: "No. I am not officially involved with OA, but I remain close to the people in BMC, and to the people in the Public Library of Science (PLoS), and to the extent that I can help them I do help."

Nevertheless, Tracz says, he is still actively engaged in science publishing, and currently involved in number of new projects. "I think there is a lot more to do in science publishing, and urgently, if we are to make research findings visible in a sensible way."

While his new projects are not OA as such, he says, his working assumption today is that whenever primary research is being published OA should be a given. "I will never do anything that is not OA in such circumstances. However, in the case of secondary publishing, where OA may not make sense, my assumption is that the reader should continue to pay - by means, say, of a subscription."

In talking about the future of scholarly communication Tracz is disarmingly frank. "What will be needed is not clear to me," he says. "But what is clear is that unrestricted access to primary research in the life sciences is essential. It's got to the point where research can't work without it. That means we will never return to a day in which access is restricted."

How would Tracz like to be remembered when the history of OA is written? "I have no need to be remembered," he replies with a laugh. "That was never my motive at all. Besides, we can never know how history is going to judge us, so why worry."
However history judges him, Tracz adds, he plans to continue playing a role in science publishing for as long as he is able.

And it is not just science publishing. Currently the web site of his company Science Navigation Group $^{125}$ lists eight companies. These range from the post-publication filtering and evaluation service in biology and medicine Faculty 1000, ${ }^{126}$ the magazine The Scientist, ${ }^{127}$ and an events database company, ${ }^{128}$ to a video site called Web of Stories ${ }^{129}$ and a company ${ }^{130}$ focused on developing applications and services for navigation and mapping on mobile phones.

*The first half of this piece was originally published as part of the Basement Interviews Project - a series of interviews with the founders of various Open and Free movements, from the Free Software Movement to Open Biology etc., that journalist Richard Poynder conducted between 2004 and 2006. The book-length project includes 12 interviews each preceded by an analytical introduction, which Poynder self-published on his personal website poynder.blogspot. com. (The complete archive of the interviews is available, for a voluntary contribution, at http://poynder.blogspot. com/2006/03/basement-interviews.html). Where suitable and possible, footnotes, links and figures in this section have been updated to reflect the situation in 2010.

The initial interview with Vitek Tracz took place in December 2004, a shortened version of which was published in Information Today, in January 2005. A follow-up conversation then took place by telephone in April 2005.

"In Retrospect: Vitek Tracz in 2010" is an update of the original interview specially prepared for the 21:1-2 issue of Logos. This latest conversation, conducted in September 2010, sheds light on OA developments and Vitek Tracz's projects in particular, that have taken place in the six years since the first interview. 


\section{Endnotes}

1 Science Navigation Group is the holding company for a number of different businesses, including BioMed Central. http://science-navigation-group.com/default.asp

2 http://www.sciencedirect.com.

3 At the time of this publication, arXiv contained 632,141 "e-prints in Physics, Mathematics, Computer Science, Quantitative Biology, Quantitative Finance and Statistics". http://www.arxiv.org.

4 See for instance Stevan Harnad's 1994 Subversive Proposal. http://www.arl.org/scomm/subversive/sub01.html

5 Between 1986 and 2003, the price per subscription of serials rose by $215 \%$, compared to a rise in the Consumer Price Index of only 68\%. http://en.wikipedia.org/wiki/Serials_crisis.

6 http://en.wikipedia.org/wiki/Open_access.

7 STM publishers generally insist that researchers assign to them the copyright in all the papers published, thereby handing over exclusive rights to the publisher. In effect, argue open access advocates, researchers freely give to publishers research that has been publicly funded, and the publishers then sell that research back to researchers' institutions in the form of journal subscriptions. As such, they say, publishers are profiting unduly from the taxpayer.

8 http://www.opensource.org/history.

9 Most notably, in July 2004 the world's second largest STM publisher, Springer, announced the launch of Open Choice. (http://www.springer.com/about+springer/media/ pressreleases?SGWID=0-11002-2-803577-0).

10 http://www.nih.gov.

11 http://www.ncbi.nlm.nih.gov/pmc/.

12 In practice, publishers chose instead to develop "all you can eat" subscription licences (known as "The Big Deal"). These, however, turned out to be even more controversial. See for instance: http://dlib.anu.edu.au/dlib/march01/ frazier/03frazier.html.

13 Originally conceived as a way of engineering a "radical transformation of the way biomedical research is published" called E-Biomed, by the time the service was launched as PubMed Central it had become a pale shadow of Varmus's original vision.

14 http://www.parliament.uk/business/committees/committees-archive/science-technology/.

15 (http://en.wikipedia.org/wiki/Ian_ Gibson_\%28politician\%29).
16 http://www.parliament.uk/parliamentary_committees/science_and_technology_committee/scitech111203a.cfm.

17 http://www.wellcome.ac.uk/News/Media-office/Press-releases/2005/WTX026822.htm.

18 http://www.the-scientist.com/news/display/23341.

19 Scientific Publications: Free for All? http://www.publications.parliament.uk/pa/cm200304/cmselect/cmsctech/399/39902.htm.

20 In any case, the British Government declined to intervene, passing the decision on to the Research Councils UK (which has yet to finalise its policy on OA). See footnote 87.

21 The NIH policy is known formally as the "Policy on Enhancing Public Access to Archived Publications Resulting from NIH-Funded Research". The policy "requests" scientists to voluntarily deposit electronic copies of their final, peer-reviewed manuscripts in NIH's PubMed Central database, "as soon as possible" after acceptance for publication. Authors can specify when their manuscripts will be publicly released, anywhere from immediately to 12 months after publication. The policy places the burden on scientists to resolve copyright disputes with journal publishers, which many have argued is a major disincentive. Certainly, in a January 2006 report to Congress NIH Director Elias Zerhouni said that less than 4\% of eligible articles were added to PubMed Central during the first eight months of the policy enactment. It is for this reason that new initiatives like the CURES Act and the FRPAA have been introduced. http://grants.nih.gov/ grants/guide/notice-files/NOT-OD-05-022.html.

22 The CURES Act, which in 2006 was still "in committee", would create a new agency within the NIH, the American Center for Cures, whose primary mission would be to translate fundamental research into therapies. Its aims are not limited to OA, but it would "require" deposit of research papers at the time of publication. CURES also extends the OA policy beyond the NIH to the other agencies within the Department of Health and Human Services, including the Centers for Disease Control and Prevention and the Agency for Healthcare Research. http://www. earlham.edu/ peters/fos/newsletter/01-02-06.htm\#cures.

23 More specifically the FRPAA - introduced on May 2nd 2006, by Senators John Cornyn (R-TX) and Joe Lieberman (D-CT) - would require that US Government agencies with annual extramural research expenditures of over $\$ 100$ million make manuscripts of journal articles stem- 
ming from research funded by that agency publicly available via the Internet. The manuscripts would need to be maintained and preserved in a digital archive maintained by the agency concerned, or in another suitable repository that permitted free public access, interoperability, and long-term preservation. Each manuscript would need to be freely available to users without charge within six months of being published in a peer-reviewed journal. In embracing 11 federal funding agencies it is considerably wider than medicine alone, and so broader in scope than CURES. http://www.arl.org/sparc/advocacy/frpaa/index. shtml (As noted in the 2010 update the first iteration of FRPAA died in committee, but a new version was re-introduced in September 2009).

24 The proposal has seen one supporter of OA publishing - professor Gunther Eysenbach, from the department of health policy at the University of Toronto - complain that the FRPAA "would force authors who have already published their work in open access journals, like the family of journals published by the Public Library of Science (PLoS), to go through the motions of republishing in the federal repositories."

25 Both BMC and the other major OA publisher, Public Library of Science (PloS) make their papers available on their web sites from the day of publication. They also deposit them in PubMed Central.

26 http://web.archive.org/web/20041213053556/www.epsltd. com/press/pr.28.10.2004.asp.

27 In 2006 93\% of scholarly publishers permitted their authors to self-archive their papers. http://romeo.eprints. org/stats.php. Many traditional publishers have also introduced OA "choices" for authors willing to pay to have their papers openly available, including Springer, Oxford University Press and Blackwell Publishing.

28 Between 1998 and 2006 Elsevier spent $\$ 12.5$ million on lobbying in the US, the fourth largest amount of any UK company. A key piece of Elsevier lobbying took place in the fall of 2004. In July, Congress directed the NIH to adopt an OA policy, in July and August the agency hammered out its first draft, and from September 2 nd to November 16th it collected public comments on the result. http://www.earlham.edu/ peters/fos/2006_01_22_fosblogarchive.html\#113776724686230221.

29 BMC does also operate an institutional membership scheme that allows libraries to buy a variety of bulk payments schemes on behalf of researchers, but this is viewed (by librarians at least) only as a way of supporting Open Access until it is more firmly established. http:// www.biomedcentral.com/info/about/instmembership. In March 2004, BMC also attracted criticism from librarians when it changed the basis of payment for its institutional membership fees. http://www.libraryjournal.com/article/ CA386750.html.

30 Information provided by BMC's Matt Cockerill in an email on 15th May 2006.

31 Currently PLoS charges between $\$ 1,350$ and $\$ 2,900$ per paper, and Springer's Open Choice charges $\$ 3,000$. For a comparative APC chart see: http://www.biomedcentral. com/info/authors/apccomparison.

32 http://www.nutritionandmetabolism.com.

33 http://www.the-scientist.com/news/display/23352. (It is worth noting that The Scientist is another of Tracz's businesses).

34 An important principle established by OA publishers early on was that those who cannot afford to pay the APC, particularly researchers in the developing world, should be able to have their fees waived. In 2006 Feinman could waive around $35 \%$ of the papers in Nutrition and Metabolism, on a discretionary basis. Under the new contract, $\mathrm{BMC}$ editors argued, the waiver rate would be reduced.

35 http://www.ij-healthgeographics.com.

36 http://www.biology-direct.com.

37 http://www.library.yale.edu/ 1license/ListArchives/0605/ msg00073.html.

38 http://www.springer.com/about+springer/media/pressrelea ses?SGWID=0-11002-2-803740-0.

39 http://www.equityhealthj.com.

40 http://www.journal-inflammation.com.

41 http://www.publications.parliament.uk/pa/cm200304/cmselect/cmsctech/uc399-ii/uc39902.htm.

42 http://en.wikipedia.org/wiki/Fitzrovia.

43 http://www.ucl.ac.uk.

44 Andrzej Krause is a Polish graphic/poster designer. http:// www.guardian.co.uk/gall/0,8542,575866,00.html.

45 A shtetl or shtetele (diminutive form of Yiddish shtot, "town") was typically a small town or village with a large Jewish population in pre-Holocaust Central and Eastern Europe. Shtetls were mainly found in the areas which constituted the 19th century Pale of Settlement in the Russian Empire, the Congress Kingdom of Poland, Galicia, and Romania. http://en.wikipedia.org/wiki/Shtetl.

46 Trotskyism is the theory of Marxism as advocated by Leon Trotsky. On the political spectrum of Marxism, Trotskyists are considered to be on the left. http://en.wikipedia. org/wiki/Trotskyite.

47 The Comintern (Communist International), also known 
as the Third International, was an international Communist organisation founded in March 1919 by Vladimir Lenin, Leon Trotsky and the Russian Communist Party (Bolshevik), which intended to fight "by all available means, including armed force, for the overthrow of the international bourgeoisie and for the creation of an international Soviet republic as a transition stage to the complete abolition of the State."

48 Following the Further and Higher Education Act, 1992 the London Polytechnic was renamed the University of Westminster. http://en.wikipedia.org/wiki/London_Polytechnic.

49 The Slade School of Fine Art is an art school based at University College, London (London University) in the UK. The school traces its roots back to 1868 when Felix Slade decided to establish three Chairs in Fine Art, to be based at Oxford, Cambridge and London - though with only London offering studentships. Many of the most accomplished and influential British artists have since studied at the Slade, which operates two studios: one for undergraduate students, the other for postgraduates only. Lucian Freud, Reg Butler and Roger Fry are among the many distinguished past members of the teaching staff. http://en.wikipedia.org/wiki/Slade_school_of_art.

50 The film was not about any specific Queen of Sweden, but was an allegory.

51 Tim Hailstone went on to buy and sell around 20 publishers and businesses and is currently chairman of the UK The Stationery Office. http://news.ft.com/cms/s/d5bdc160-fc0a-11d8-bb3a-00000e2511c8,ft_acl=.html.

52 Churchill Livingstone is now part of the Reed Elsevier Empire. http://en.wikipedia.org/wiki/Churchill_Livingstone.

53 Harper \& Row was bought by Murdoch in 1987. Harper \& Row was merged with William Collins to become HarperCollins in 1990, and Gower was sold to Kluwer, and then on to Times-Mirror in 1993. Gower was subsequently sold to Lippincott Williams \& Wilkins, a unit of Wolters Kluwer Health, which decided not to continue production of Gower's colour atlas products when they went out of print in the 1990s. (http://www.gowerpub.com/).

54 http://scientific.thomson.com/products/coddd.

55 In 2008 The Thomson Corporation merged with Reuters Group PLC to form Thomson Reuters http://thomsonreuters.com/.

56 http://www.computeractive.co.uk/information-world-review/news/2079875/biomedics-start-purchases-online.

57 http://www.questel.orbit.com/Piug/piugl_97/0694.html.
58 The remnants of BioMedNet are here: http://www.bmn. com.

59 Now also part of the Elsevier empire. (http://www.elsevierdirect.com/brochures/academicpress/index.html).

60 Current Contents is a current awareness service consisting of the tables of contents of medical, pharmaceutical and chemical journals. http://scientific.thomson.com/ products/ccc.

61 Medline is the core content in PubMed, a service of the US National Library of Medicine (see footnote 69) http:// medline.cos.com.

62 A bibliographic database of around 28 million patents called World Patents Index. http://scientific.thomson. $\mathrm{com} /$ products/dwpi.

63 Chemist Monty Hyams founded Derwent Information in 1949. http://dspace.dial.pipex.com/town/parade/df04/ Monty\%20Hyams.htm.

64 Investigational Drugs Database has meanwhile transformed into Thomson Pharma Partnering http://www. iddb3.com/; http://partnering.thomson-pharma.com/.

65 http://www.biomedcentral.com.

66 David Lipman is director of the US National Institutes of Health (NIH) National Center for Biotechnology Information (NCBI), and the National Library of Medicine (NLM). http://www.ncbi.nlm.nih.gov/CBBresearch/Lipman.

67 PubMed is a Web-based retrieval system developed by the NCBI at the National Library of Medicine. It is part of NCBI's vast retrieval system, known as Entrez, and contains more than 16 million citations.

68 GenBank is the NIH genetic sequence database, an annotated collection of all publicly available DNA sequences. As of February 2006, there were approximately $59,750,386,305$ bases in 54,584,635 sequence records in the traditional GenBank divisions and 63,183,065,091 bases in 12,465,546 sequence records in the WGS (Whole Genome Shotgun) division.

69 Harold Varmus, who is a Nobel Prize laureate, was at that time director of the NIH. http://nobelprize.org/medicine/ laureates/1989/varmus-autobio.html.

70 http://www.nih.gov/about/director/pubmedcentral/ebiomedarch.htm.

71 EMBASE is also part of the Elsevier Empire. The company describes EMBASE as "the most current biomedical database available today." Articles appear in the database, on average, within two weeks of receipt of the original journal. Each record contains the full bibliographic citation, indexing terms and codes; $80 \%$ of all citations 
in EMBASE include author-written abstracts. EMBASE contains over 11 million records from 1974 to 2006, with over 500,000 citations and abstracts added annually. These records reflect all current developments in biomedical and drug-related fields. EMBASE also has over 7 million unique MEDLINE records from 1966 to 2006. www.embase.com.

72 http://www.physics.cornell.edu/people/. faculty/?page=website $/$ faculty\&action $=$ show $/ \mathrm{id}=17$.

73 arXiv (pronounced "archive", as if the "X" were the Greek letter $\chi$ ) is an archive for electronic preprints of scientific papers in the fields of physics, mathematics, computer science and biology which can be accessed via the Internet. In many fields of mathematics and physics, almost all scientific papers are placed on the arXiv, with some work, including even very influential papers, remaining purely as e-prints and not published in peer-reviewed journals. At the time of this publication, arXiv.org contained about 632,141e-prints, with roughly five thousand new e-prints being added every month. www.arxiv.org.

74 Patrick Brown is a Stanford geneticist and a co-founder of Public Library of Science (PLoS). http://www.plos.org/ about/board.html\#Brown.

75 Michael Eisen is a computational and evolutionary biologist at Ernest Orlando Lawrence Berkeley National Laboratory and also a co-founder of PLoS. http://www.plos.org/ about/board.html\#Eisen.

76 The Public Library of Science initiative began with the circulation of an open letter urging scientific publishers to allow the research papers that have appeared in their journals to be distributed freely by independent, online public libraries of science. The letter was signed by nearly 34,000 scientists from 180 countries, but had little impact on publisher practice, or on Open Access. The founders of PLoS therefore decided to turn the organisation they had created into an OA publisher. http://www.plos.org/ about/letter.html.

77 Launched in 1986, The Human Genome Project (HGP) was developed to map the human genome down to the nucleotide (or base pair) level and to identify all the genes present in it. It was coordinated by the US Department of Energy, the NIH and, the UK-based Wellcome Trust. In 1998 the American researcher Craig Venter and his firm Celera Genomics launched an identical, privately funded, project. The $\$ 300$ million Celera effort was intended to proceed at a faster pace and at a fraction of the cost of the roughly $\$ 3$ billion taxpayer-funded project. The competition proved to be very good for the project. Initially the ri- vals agreed to pool their data, but the agreement fell apart when Celera refused to deposit its data in the unrestricted public database GenBank. Celera had incorporated the public data into their genome, but forbade the public effort to use Celera data. On 14 April 2003, a joint press release announced that the project had been completed by both groups, with $99 \%$ of the genome sequenced with 99.99\% accuracy. In 2005, in a decision that essentially marked the end of the genome wars, Celera Genomics announced it would release its formerly proprietary human, mouse, and rat genome sequences into the public domain. The decision went into effect on July 1 st 2005. http://www.bio-itworld.com/newsitems/2005/06-05/0609-05-news-celera.

78 http://www.publications.parliament.uk/pa/cm200304/cmselect/cmsctech/399/39902.htm.

792005.

80 The company has still to achieve profitability, but see Matt Cockerill's comment in the introduction. (See also Tracz's claim in 2010 that with BMC he proved that OA publishing is sustainable [as he put it, BMC has shown that "OA is feasible, it is practical and it is possible"]. Finally, note Derk Haank's similar claim about sustainability when Springer acquired BMC: http://www.springer.com/ authors/author+zone?SGWID=0-168002-12-563100-0.

"This acquisition reinforces the fact that we see open access publishing as a sustainable part of STM publishing, and not an ideological crusade." One might wonder that neither Tracz nor Haank described BMC as profitable)

81 As noted in the introduction, in May 2006 this figure was 1,200 submissions a month.

82 As noted in the introduction, in a January 2006 report to Congress NIH Director Elias Zerhouni said that less than $4 \%$ of eligible articles were added to PubMed Central during the first eight months of the policy enactment.

83 Indeed, the recently announced FRPAA suggests that the US could be about to lead the world on mandating OA.

84 See the introduction: in October 2005 the Wellcome Trust introduced a mandate requiring that all papers resulting from research that it funds are made Open Access. http://www.wellcome.ac.uk/News/Media-office/Press-releases/2005/WTX026822.htm.

85 Despite the publication of a position statement on OA in June 2005, by 2006 Research Councils UK had still not introduced an OA policy. By 2010, however, all the research councils had, on their own initiative, introduced mandate: http://www.researchinformation.info/news/ news_story.php?news_id=436. 
86 In March 2005 four major French public research agencies - INRA, CNRS, INRIA, and Inserm - issued a joint press release announcing a common policy to launch $\mathrm{OA}$ archives to disseminate their research output. http://www. earlham.edu/ peters/fos/2005_03_20_fosblogarchive. html\#111154472103008317.

87 By 2006 as reported on http://romeo.eprints.org/stats.php.

88 In September 2004, BioMed Central announced that in the wake of the UK House of Commons Science \& Technology Committee report (Scientific Publications: Free for all?), it was launching a repository service for universities and research institutions. http://www.biomedcentral. com/info/about/pr-releases?pr=20040913.

89 In 2007 Blackwell Publishing was acquired by Wiley, who merged its publishing program with its global scientific, technical and medical business. http://eu.wiley.com/WileyCDA/Section/id-301697.html.

90 http://www.infotoday.com/IT/sep03/poynder.shtml.

91 http://www.infotoday.com/newsbreaks/nb041115-1.shtml.

92 www.chemistry.org.

93 In September 2004, the Editor-in-Chief of ACS's Chemical \& Engineering News Rudy Baum published an editorial denouncing Open Access as "Socialized Science". http://pubs.acs.org/cen/editor/8238edit.html.

94 Barnes is in southwest London, in the London Borough of Richmond upon Thames. It has some of the most expensive housing in London, prized for its relatively secluded location (the river acts as a barrier to much through traffic) and its elegant mansions. http://en.wikipedia.org/ wiki/Barnes,_London.

95 See in this context the incipient Open Data Movement: http://www.arl.org/sparc/innovator/panton.shtml.

96 i.e. the research papers that $\mathrm{OA}$ advocates are calling to be made Open Access.

97 Nikita Sergeyevich Khrushchev was the leader of the Soviet Union after the death of Joseph Stalin. He was First Secretary of the Communist Party of the Soviet Union from 1953 to 1964 and Chairman of the Council of Ministers from 1958 to 1964. He was removed from power by his party colleagues in 1964 and replaced by Leonid Brezhnev. He spent the last seven years of his life under house arrest. http://en.wikipedia.org/wiki/Nikita_Khrushchev.

98 In 1956 Khrushchev ordered the suppression of the Hungarian Revolution. Also known as the Hungarian Uprising or simply the Hungarian Revolt, the Hungarian Revolution was an anti-Soviet revolt in Hungary lasting from 23rd October to 4th November 1956. The revolt was suppressed by Soviet troops, and to a much smaller degree the Hungarian ÁVH. http://en.wikipedia.org/wiki/1956_ Hungarian_Revolution.

99 http://www.libraryjournal.com/article/CA6602778.html. 100 http://en.wikipedia.org/wiki/Open_access_publishing.

101 http://en.wikipedia.org/wiki/Hybrid_open_access_journal.

102 http://www.springer.com/open+access/open+choice?SG $\mathrm{WID}=0-40359-0-0-0$.

103 http://www.biomedcentral.com/info/about/apcfaq.

104 http://www.infotoday.com/it/sep04/poynder.shtml.

105 http://www.eprints.org/openaccess/policysignup/.

106 http://eprints.ecs.soton.ac.uk/13309/.

107 http://publicaccess.nih.gov/.

108 http://www.taxpayeraccess.org/issues/frpaa/index.shtml.

109 http://www.libraryjournal.com/article/CA6668699.html.

110 http://www.earlham.edu/ peters/fos/2009/02/conyers-billis-back.html.

111 Ibid.

112 http://chronicle.com/article/Lawmakers-Hear-Arguments-fo/123719/.

113 http://www.biomedcentral.com/info/authors/ apcfaq/\#howmuch.

114 http://www.oxfordjournals.org/oxfordopen/.

115 http://www.nature.com/ncomms/open_access/index. html.

116 http://www.cell.com/cellpress.

117 http://www.springeropen.com/.

118 http://www.biomedcentral.com/info/about/membership.

119 http://library.cpmc.columbia.edu/hsl/index.html.

120 http://scholarlykitchen.sspnet.org/2009/11/09/open-access-memberships-are-libraries-paying-too-much/.

121 http://www.springer.com/about+springer/media/pressrele ases?SGWID=0-11002-6-987121-0.

122 http://www.helmholtz.de/en/.

123 http://www.earlham.edu/ peters/fos/2009/01/springerfirst-us-deal-in-which.html.

124 http://poynder.blogspot.com/2009/03/open-access-whowould-you-back.html.

125 http://sciencenavigation.com/.

126 http://f1000.com/.

127 http://sciencenavigation.com/company_sci.asp.

128 http://www.gdp.co.il/Home_EN.aspx.

129 http://www.webofstories.com/.

130 http://global.telmap.com/. 